\title{
Measurement methods in marine engine endoscopy
}

\begin{abstract}
The paper presents selected metrological techniques that may be applied in diagnostic endoscopy in complex machinery including turbine and piston marine engines. The evolution of contemporary endoscopes has been described as well as theoretical background for optical and digital endoscopy. The methods of surface defect measurements of selected elements of marine engine structure have been presented based on a digital recording of endoscopic images: Stereo Probe, Shadow Probe, laser method and $R G B$.
\end{abstract}

Key words: marine engine, technical diagnostic, endoscopy, measurement mothods

\section{Metody pomiarowe stosowane w endoskopii silników okrętowych}

\begin{abstract}
W opracowaniu przedstawiono wybrane techniki metrologiczne, które mogq znaleźć zastosowanie w diagnostycznych badaniach endoskopowych złożonych obiektów technicznych, w tym silników okrętowych - tlokowych i turbinowych. Przybliżono ewolucję wspótczesnych endoskopów oraz podstawy teoretyczne endoskopii optycznej i cyfrowej. Zaprezentowano metody pomiaru defektów powierzchniowych wybranych elementów struktury konstrukcyjnej silników okrętowych, które bazuja na cyfrowym zapisie obrazu endoskopowego: metodę Stereo (,, Stereo Probe”), metodę Cienia (,, Shadow Probe"), metodę laserowa, metodę RGB.
\end{abstract}

Słowa kluczowe: silnik okrętowy, diagnostyka techniczna, endoskopia, metody pomiarowe

\section{Introduction}

A constant development and evolution of diagnostic systems applied in marine piston and turbine combustion engines enables an extension of the functions of the inspection systems by not only measurement of operating parameters but also image recording in the internal space of the engine.

Contemporary piston engines are fitted with sophisticated control systems measuring load characteristics. The basis for routine diagnostic tests is indicating of the engine cylinders under steady operation at representative load ranges. A comparative statistical and content related analysis with the use of analyzers of fast changing values is performed as regards indicator graphs, courses of accelerations (generated by the operation of the mechanisms related to the piston assembly transmitted to the measuring point on the top of the cylinder head) and the courses of other values characterizing the operating processes in the engine cylinders throughout its cycle. So determined diagnostic measures: mean indicated pressure, indicated power output, maximum combustion pressure and the speed of in-cylinder pressure growth $\mathrm{dp} / \mathrm{d} \alpha_{\text {owK }}$ etc. provide important information on the general condition of the elements of the combustion system. The test results are used to determine the trends, analyze the changes in the engine condition and make decisions as to further operation.

Nevertheless, in practice, cases of serious engine damage are known caused e.g. by mechanical stability loss leading to a torsional resonance as a consequence of an excessive load spread whose sources were not identified in due time. The occurring torsional vibration of high amplitudes have a destructive impact on the engine and the whole drivetrain of a ship as they cause material fatigue and finally cracking

\section{Wprowadzenie}

Ciągłe unowocześnianie i zwiększanie możliwości systemów pomiarowo-diagnostycznych stosowanych w siłowniach okrętowych o napędzie z tłokowymi i turbinowymi silnikami spalinowymi, pozwala na rozszerzenie funkcji systemu kontroli, włączając w nie, oprócz standardowego pomiaru parametrów eksploatacyjnych, także funkcje rejestracji obrazu przestrzeni wewnętrznych silników napędowych.

Współczesne silniki tłokowe wyposażone są w coraz doskonalsze kompleksowe systemy kontrolno-pomiarowe, mierzące parametry charakteryzujące stan ich obciążenia. Podstawą realizacji rutynowych badań diagnostycznych jest kolejne indykowanie cylindrów silnika w stanie pracy ustalonej na reprezentatywnych zakresach obciążenia. Z wykorzystaniem specjalistycznych analizatorów wielkości szybkozmiennych przeprowadza się porównawczą analizę statystyczną i merytoryczną rozwiniętych wykresów indykatorowych, przebiegów przyspieszeń drgań generowanych pracą mechanizmów związanych z układem cylindrowym transmitowanych do punktu pomiaru na powierzchni głowicy oraz przebiegów innych wielkości charakteryzujących procesy robocze $\mathrm{w}$ cylindrach silnika, sporządzonych w dziedzinie kata obrotu wału korbowego. Wyznaczane w ten sposób miary diagnostyczne: średnie ciśnienie indykowane, moc indykowana, maksymalne ciśnienie spalania i szybkość wzrostu ciśnienia wewnątrzcylindrowego $\mathrm{dp} / \mathrm{d} \alpha_{\text {owK }}$ itp. dają ważną informację o ogólnym stanie technicznym elementów konstrukcyjnych zespołu komory spalania. Wyniki badań wykorzystywane są w analizie trendów, do oceny zmian stanu technicznego silników i do wypracowania decyzji eksploatacyjnej. 
of the constructional elements of the torque transmission to the propeller or the bearing nodes.

Similarly, it is difficult to assess the condition of a piston engine based on the operating parameters if the operation of the fuel delivery system is improper. Frequently, the trend lines of the changes in the temperature of the exhaust from individual cylinders change their course to a small extent only and the effect of a failure of one of the injectors is that the piston crown is damaged.

The difficulties in damage diagnosis in the flow part of turbine engines based on the measured thermodynamic parameters that characterize the energy state of the flowing medium are dependent on appropriate interpretation of the symptoms of the defect which are often identified as consequences of constant and inevitable processes of fouling, ageing and deterioration determined by the period of operation. The external symptoms in such states are usually concurrent and difficult to precisely determine. A special case is the problem of diagnostic parameter analysis needed to assess the extent of fouling in the flow channels of the fan assemblies and the effectiveness of their cleaning. A classic mistake in interpretation of the symptoms is the incorrect differentiation of the operating foul of the flow part as a constant process accompanying the engine operation under marine conditions from the state of its inability to operate properly caused by e.g. burning of the edges of the vanes of the turbine. Such a situation may take place as a result of a lack of cleaning of the flow part of the turbine, which, among other things, improves the cooling of the vanes.

Another example of faulty diagnostic reasoning is the assessment of the condition of a turbine engine based on the distribution of the stream of enthalpy throughout the length of the flow part and the evenness of the temperature field of the exhaust on the circumference of the control cross-section downstream the exhaust generator. Very often the slip in the turbine speed and the circumferential temperature distribution unevenness change only slightly and the effect of the injector failure leads to a burning of the flame tube in the combustion chamber. That is why, each time (if the technical conditions allow) on confirming the deformations of the gas dynamic characteristics an endoscopic inspection of the flow part is performed in order to finally validate the diagnosis.

A direct visual inspection of machine elements is the oldest method of assessing their deterioration and identifying damage. This however requires visual access. It is not possible in the case of elements inside the operating sections of the engines or the flow part of turbine engines without prior disassembly. The initial periscope application in the 1970s and 1980s was quickly changed to fiber optics called endoscopes. Hence, one of the methods to obtain an arbitrary diagnosis of the condition of marine piston and turbine engines in operation is a visual examination of their internal sections with the use of endoscopes. Any possible doubts of a diagnostic technician as to:

\section{What is happening inside the machine}

Are cleared in a non-invasive, quick cheap and more importantly, unambiguous way:
Pomimo tego, w praktyce eksploatacyjnej znane sa przypadki dużych uszkodzeń silników, spowodowanych np. utratą stabilności ich układu mechanicznego i pojawienia się zjawiska rezonansu drgań skrętnych, jako konsekwencji nadmiernego rozrzutu obciążeń pomiędzy cylindrami silnika, którego pierwotne przyczyny nie zostały w porę zidentyfikowane. Występujące wówczas drgania skrętne o znacznych amplitudach mają destrukcyjny wpływ na konstrukcję silnika i całej linii napędowej okrętu, gdyż powodują zmęczenie materiału i w konsekwencji pękanie elementów struktury konstrukcyjnej układu transmisji momentu obrotowego do pędnika okrętowego czy węzłów łożyskowych.

Podobnie trudno jest ocenić stan silnika tłokowego na podstawie parametrów eksploatacyjnych przy uszkodzeniach układu zasilania silnika paliwem. Często linie trendu zmian wartości temperatury spalin z poszczególnych cylindrów zmieniają swój przebieg tylko nieznacznie, a w wyniku defektu jednego z wtryskiwaczy przepaleniu ulega denko tłoka.

Natomiast trudności rozpoznawania uszkodzeń w części przepływowej turbinowego silnika spalinowego na podstawie zmian mierzonych parametrów termodynamicznych, charakteryzujących stan energetyczny przepływającego czynnika roboczego, związane są z właściwą interpretacją symptomów powstałego defektu, które często identyfikowane są jako symptomy nieuniknionych i ciagłych procesów zanieczyszczenia, starzenia i zużycia silnika, zdeterminowanych czasem jego eksploatacji. Zewnętrzne objawy w takich stanach są zazwyczaj zbieżne i trudne do jednoznacznego określenia. Szczególnym przypadkiem może być tutaj problem, jakim jest analiza parametrów diagnostycznych potrzebnych do oceny intensywności zanieczyszczenia kanałów przepływowych zespołów wirnikowych, a także efektywności ich mycia. Klasycznym wręcz przykładem błędnej interpretacji symptomów diagnostycznych jest niepoprawne rozróżnienie stanu eksploatacyjnego zanieczyszczenia części przepływowej, jako ciagłego procesu towarzyszącego pracy silnika w warunkach morskich, od stanu jego niezdatności, spowodowanej na przykład nadpaleniem wierzchołków łopatek wirnikowych turbiny. Do takiej sytuacji może dojść wskutek nieprzeprowadzonego w porę lub przeprowadzonego nieskutecznie mycia części przepływowej, które między innymi poprawia efektywność chłodzenia łopatek.

Innym przykładem błędnego wnioskowania diagnostycznego jest ocena stanu technicznego silnika turbinowego na podstawie rozkładu strumienia entalpii na długości części przepływowej i równomierności pola temperatury spalin wylotowych na obwodzie przekroju kontrolnego za wytwornicą spalin. Często poślizg prędkości obrotowej zespołów wirnikowych silnika i wskaźnik nierównomierności obwodowego rozkładu temperatury spalin zmieniają się tylko nieznacznie, a w wyniku defektu wtryskiwacza przepaleniu ulega rura ogniowa komory spalania. Dlatego każdorazowo (jeśli pozwalają na to warunki techniczne), po stwierdzeniu deformacji charakterystyk gazodynamicznych silnika, w celu ostatecznej weryfikacji postawionej diagnozy, przeprowadza się przegląd endoskopowy części przepływowej. 
A pre-requisite - „ktema es aei” - is however the technician's knowledge and expertise on popular and identifiable malfunctions that have occurred in these machines before.

Many years of systematic endoscopic examinations carried out within the periodic preventive inspections of marine engines used in the Polish Navy showed a high level of effectiveness of this method with a simple use of the test equipment.

\section{Endoscopy - a historical sketch}

Visual examination of internal spaces of machines and industrial equipment with the use of endoscopes is currently the basic method of technical diagnosis. The surface structure of the construction material is seen as if through a magnifying glass during the examination which enables detection, identification and quantitative assessment of the malfunctions and material defects eventually leading to the assessment of the level of deterioration and fouling of the constructional elements. Depending on the method of observation and image processing of a surface under examination we can differentiate a classic optical endoscopy utilizing rigid (lens based) borescopes and flexible fiber glass fibroscopes and dynamically developing digital endoscopy utilizing highly sophisticated videoscopes fitted with high resolution micro cameras.

The history of endoscopy, which has its roots in medicine, is very long - it dates back to the times of Hypokrates. Ancient doctors were fascinated by the possibility of looking into the internal parts of a living human body within the reach of human eye illuminating the examined sections with sunlight reflected from a mirror. The oldest chronicles confirm that complex operations of the oral cavity, throat, nose, ear or rectum were performed with the help of a special endoscope - a predecessor of the laryngoscope. The most vital limitation for deeper exploration of the human viscera was lack of special optically shaped speculum and more importantly, lack of sufficient source of light to illuminate the internal parts of the human body. An inventor of a breakthrough device in this matter was a German doctor of Italian origin Philipp Bozzini (1773-1809) who in 1806 in the Medical School of Vienna demonstrated a quasi-endoscope under the name of lichtleiter (light conductor) used to examine the women's urinary bladder (Fig. 1) [4, 11]. The basis of the design of this device was a speculum head fitted with a candle as a source of light and mirror partitions directing the light onto the examined organs. The original Bozzinis light conductor can be seen in Chicago USA (American College of Surgeons).

Later versions of the light conductor much more perfect in design came to resemble contemporary borescopes (Fig. 2 ). These are rigid optics of various length and diameter consisting in an eyepiece, a set of cylindrical lenses, usually of the length of $20-25 \mathrm{~mm}$, a prism and a fiber optics channel which is fixed in the metal cylindrical casing. The source of light placed in the end of the probe were initially an alcohol-terpene lamp (invented by Antonin J. Desormeaux in 1853), a glowing platinum filament (patented by Maximilian Nitze in 1879 , also the author of the first photographic
Bezpośredni ogląd zewnętrzny elementów konstrukcyjnych maszyn jest najstarszym sposobem wykrycia uszkodzeń i oceny ich zużycia, co jednak wymaga dostatecznego dostępu wzrokowego. Nie jest to możliwe w odniesieniu do części znajdujących się w przestrzeniach roboczych silnika łłokowego, czy też w części przepływowej silnika turbinowego bez ich demontażu. Początkowe stosowanie systemu peryskopowego, jeszcze na przełomie lat 70. i 80. XX wieku, szybko zastapiono systemami światłowodowymi nazywanymi endoskopami. Tak więc jedną z możliwości uzyskania arbitralnej diagnozy o stanie technicznym silników okrętowych - tłokowych i turbinowych, w warunkach bieżącej eksploatacji zapewnia badanie wizualne polegające na wziernikowaniu jego przestrzeni wewnętrznych z wykorzystaniem endoskopów. W sposób bezinwazyjny, bardzo szybki, tani, a co najważniejsze jednoznaczny rozwiane zostają wątpliwości diagnosty:

\section{Co dzieje się wewnątrz tej maszyny?}

Warunkiem obligatoryjnym - „ktema es aei” - jest jednak posiadanie przez niego wystarczającej wiedzy o znanych i rozpoznawalnych uszkodzeniach, które już kiedyś w tego typu silnikach zaistniały.

Wieloletnie, systematyczne badania endoskopowe, prowadzane w ramach okresowych obsług profilaktycznych silników okrętowych eksploatowanych w Marynarce Wojennej RP, wykazały dużą skuteczność metody, przy prostej obsłudze stosowanej aparatury badawczej.

\section{Rys historyczny endoskopii}

Badanie wizualne powierzchni tworzących przestrzenie wewnętrzne maszyn i urządzeń przemysłowych z zastosowaniem specjalistycznych wzierników, tzw. endoskopów, to obecnie podstawowa metoda diagnostyki technicznej. Struktura powierzchniowa materiału konstrukcyjnego widoczna jest podczas badań jak przez lupę, zazwyczaj z pewnym powiększeniem, co umożliwia wykrycie, rozpoznanie i ewentualną ocenę ilościową występujących defektów i wad materiałowych, a w rezultacie - ocenę stopnia zużycia i zanieczyszczenia badanych elementów konstrukcyjnych. W zależności od zastosowanej metody obserwacji i przetwarzania obrazu wizyjnego badanej powierzchni wyróżnia się klasyczną endoskopię optyczną, z wykorzystaniem do tego

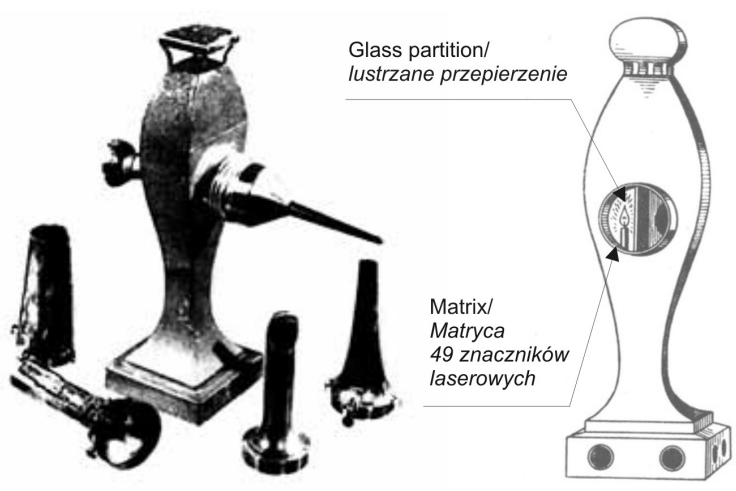

Fig. 1. Bozzini’s lightleiter [3, 10]

Rys. 1. Aparat wziernikowy Bozziniego lightliter [3,10] 
cytological atlas published in 1894) and Edison's light bulb (1879). The idea of image transmission through flexible fiber optics patented in 1926 by John Logie'a Baird the inventor of television, revolutionized the problem of borescopic illumination. Since 1965 the official solution in this matter (patented by Karl Storz) is the transmission of cold light stream to the window of the probe near the lens of the borescope through separate fiber optics from an external source of light- a halogen bulb and recently HID lamp [5]. In order to assess the emission of visible radiation of the filament characterized by different spectrum hues a notion of hue temperature of the source of light was introduced which, for halogen lamps reaches $3400 \mathrm{~K}$ and for HID lamps up to $5900 \mathrm{~K}$. for comparison the hue temperature of daylight is approximately $5500 \mathrm{~K}$ [5].

A dynamic development of fiber optics initiated by the invention of John Baird and continued in the scientific research by prof. Harold Hopkins [4] and dr. Basil Hirschowitz [4] led to a construction of a prototype of fibroscope in

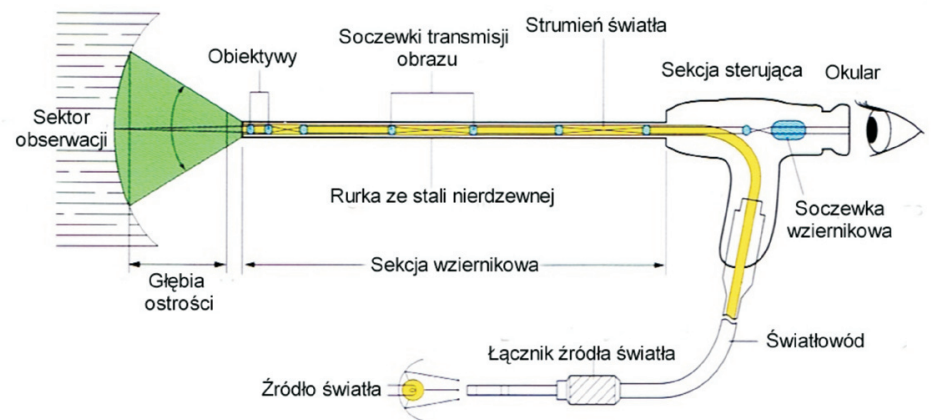

Fig. 2. Schematics of a borescope [7, 12]

Rys. 2. Schemat ideowy boroskopu [7, 12]

1957 by Aemi - an American company. This was a flexible speculum consisting of a bundle of several thousand thin (several micrometers) glass fibers transmitting optical image of an object under examination to the eye of the observer and a cold stream of light to the object under examination from an external source of light (ligh-tpipe) - a strong light bulb of an external illuminator - Fig. 3 [2]. Since each fiber glass transmits the image with different hue and brightness, it is divided into as many points as there are separate fibers in the bundle. Hence the resolution of the observed image is strictly determined by the number of fibers in the bundle. For technical reasons the number of 40,000 fibers is not exceeded (each fiber $8-10 \mu \mathrm{m}$ is covered with insulation) as it is generally accepted that such resolution is sufficient for diagnostic purposes [7].

The invention of a fibroscope has eliminated many shortcomings of a rigid borescope the most important of which is its maneuverability and security of the diagnostic examination. Unfortunately, fibroscopes also have flaws. Apart from a slightly deteriorated image quality as compared to a borescope they are very sensitive to excessive abrupt maneuvering of the speculum. This leads to cracking of the fibers which shows as black spots on the observed image - celu sztywnych (soczewkowych) boroskopów i elastycznych (światłowodowych) fibroskopów oraz dynamicznie rozwijającą się endoskopię cyfrową, z zastosowaniem coraz doskonalszych wideoskopów, wyposażonych w miniaturowe kamery cyfrowe o wysokiej rozdzielczości.

Historia endoskopii, która bierze swoje początki z medycyny jest bardzo długa - sięga czasów Hipokratesa. Już starożytni lekarze byli zafascynowani możliwością zaglądania do wewnętrznych obszarów ludzkiego, żyjącego ciała, w zasięgu dostępności ich wzroku, oświetlając je promieniami słonecznymi odbitymi od lustra. Najstarsze kroniki medyczne dowodzą, że przeprowadzano w ten sposób skomplikowane operacje jamy ustnej, gardła, nosa, ucha czy odbytu, z wykorzystaniem specjalistycznego endoskopu - poprzednika współczesnego lustra czołowego laryngologa (laryngoskopu). Najistotniejszym ograniczeniem dla głębszego wnikania do wnętrza ludzkich organów był brak wziernika wyposażonego w odpowiednio ukształtowany układ optyczny, ale co ważniejsze wyposażonego w dostatecznie silne źródło światła zewnętrznego, dające możliwość oświetlenia przestrzeni wewnętrznych organu. Twórcą przełomowego wynalazku w tym względzie był niemiecki lekarz włoskiego pochodzenia Philipp Bozzini (1773-1809), który w 1806 r. zademonstrował w Wiedeńskiej Akademii Medycznej pseudoendoskop pod nazwą lichtleiter, służący do badań pęcherza moczowego u kobiet (rys. 1) [4, 11]. Postawą konstrukcji tego wynalazku była głowica wziernikowa wyposażona w świecę, jako źródło światła oraz lustrzane przepierzenia ukierunkowujące strumień świetlny na badane narządy. Oryginalny aparat wziernikowy Bozziniego znajduje się w Chicago USA (American Collage of Surgeous).

Późniejsze, bardziej udoskonalone wersje lichtleitera coraz bardziej przypominały wyglądem współczesne boroskopy (rys. 2). Są to prętowe (sztywne) optyki, o zróżnicowanej średnicy i długości, składające się z okularu, pakietu cylindrycznych soczewek, zwykle o długości 20-25 mm, pryzmatu obiektywu oraz kanału światłowodowego, które montuje się w metalowej cylindrycznej obudowie. Źródłem światła umieszczonym w końcówce sondy (w bezpośrednim sąsiedztwie obiektywu) były początkowo lampa alkoholowoterpentynowa (wynalazek Antonina J. Desormeauxa z 1853 r.), żarząca się platynowa spirala (patent Maximilian Nitze $\mathrm{z}$ 1879 r., również autora pierwszego fotograficznego atlasu cytologiczny opublikowanego w 1894 r.), a także żarówka elektryczna Edisona (1879 r.). Opatentowana w 1926 r. przez wynalazcę telewizji Johna Logie'a Bairda idea transmisji obrazów poprzez elastyczne wiązki włókien optycznych, tzw. światłowody zrewolucjonizowała zagadnienie iluminacji boroskopowej. Od 1965 roku obowiązującym rozwiązaniem w tym względzie (patent Karla Storza) jest transmitowanie zimnego strumienia światła do okienka sondy w pobliże obiektywu boroskopu, za pośrednictwem oddzielnego światłowodu, z zewnętrznego oświetlacza wyposażonego w żarówkę halogenową, a ostatnio ksenonową [5]. Do oceny 
Fig. 4. What is interesting is that with age the flexibility of the bundle and the life cycle of the fibers is reduced. It should be noted that cracking of an individual fiber is inevitable throughout the process of fibroscope operation. It is even admissible in the manufacturing process of a new device, yet the total number of defective fibers in the bundle may not exceed 1 per mille [6].

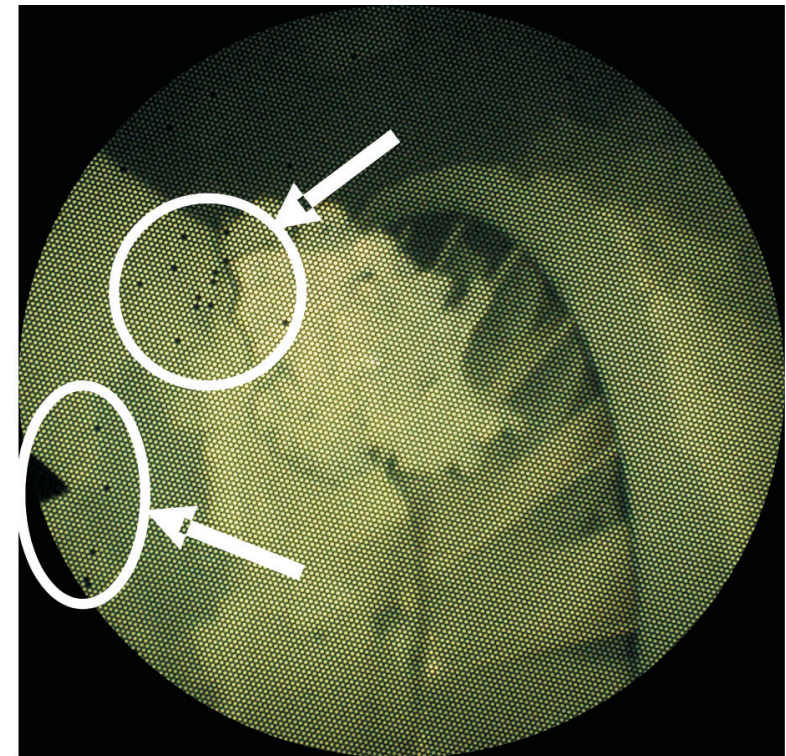

Fig. 4. Image (marine engine turbo compressor) as seen through a fibroscope with cracked fibers (black spots on the photograph) [10]

Rys. 4. Obraz obiektu (turbosprężarka silnika okrętowego) obserwowanego fibroskopem z pękniętymi włóknami wiqzki światlowodowej (czarne punkty na fotografii) [10]

A new era of endoscopy came with contemporary optoelectronics and digital technology which resulted in a construction of a videoscope in 1983 (Fig. 5). It is a digital endoscope where the fiber optics was replaced with a miniature digital camera yet, still maintaining the flexibility of the endoscope, remote maneuverability of the speculum and the light-pipe. A CCD camera processes optical image into an electronic one which is digitally transmitted via a bus into a color LCD unit. This solution generates new diagnostic possibilities such as the ability of qualitative assessment of the surface deterioration (the possibility to measure the detected structural changes - defects, discolorations, contrast etc. Another important advantage is the high resolution of the image reaching several hundred thousand pixels which ensures sharpness even under poor illumination. A digital recording of the image as videoinformation in e.g. JPEG can be transmitted on long distances (cellular networks, the internet). This allows a multilateral didactic (training and exchange of experience) or specialized consultations aiding the process of diagnostic reasoning.

\section{Measurement methods applied in digital endoscopy}

During an endoscopic inspection of the internal parts of machines we often lack reference for determining of the

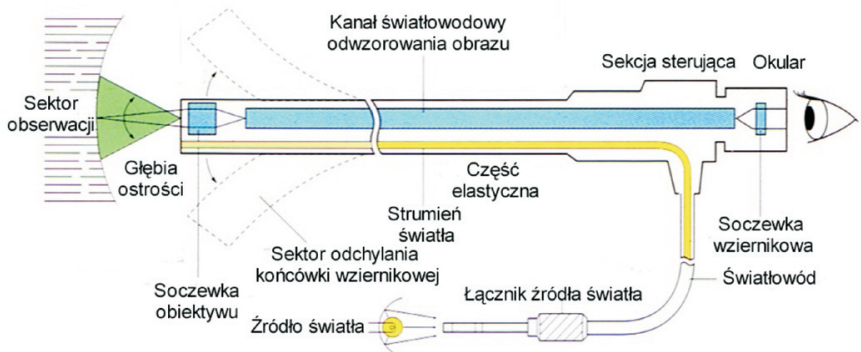

Fig. 3. Schematics of a fibroscope [7, 12]

Rys. 3. Schemat ideowy fibroskopu [7, 12]

emisji promieniowania widzialnego żarnika, charakteryzującego się różnymi barwami widmowymi, wprowadzono pojęcie temperatury barwy źródła światła, która dla żarówek halogenowych osiaga wartość do $3400 \mathrm{~K}$, a dla żarówek ksenonowych - do $5900 \mathrm{~K}$. Dla porównania, temperatura barwy źródła światła dziennego wynosi około 5500 K [5].

Dynamiczny rozwój technologii światłowodowej, zapoczątkowany przez wynalazek Johna Bairda i kontynuowany w badaniach naukowych prof. Harolda Hopkinsa [4], a także dra Basila Hirschowitza [4] pozwolił na skonstruowanie w 1957 r., przez amerykańską firmę Aemi prototypu fibroskopu - elastycznego, giętnego wziernika składającego się z wiązki kilkudziesięciu tysięcy ultracienkich (kilka mikrometrów) włókien szklanych transmitujących optyczny obraz badanego obiektu do obserwatora (obrazowód) oraz przewodzących zimny strumień świetlny do badanego obiektu z zewnętrznego źródła światła (światłowód) - silna żarówka zewnętrznego oświetlacza (rys. 3) [2]. Ponieważ każde z włókien szklanych transmituje obraz obiektu o zróżnicowanej barwie i jasności, jest on podzielony na tyle punktów, ile pojedynczych włókien szklanych zawiera wiązka światłowodowa. A zatem rozdzielczość obserwowanego obrazu jest ściśle zdeterminowana liczbą włókien światłowodu. Ze względów technologicznych nie przekracza się liczby 40000 włókien (każde włókno o średnicy $8-10 \mu \mathrm{m}$ jest pokryte warstwą izolacyjna), uznając, że taka rozdzielczość jest w zupełności wystarczająca na potrzeby diagnostyczne [7].

Wynalezienie fibroskopu wyeliminowało wiele wad sztywnych boroskopów, z których najistotniejsza dotyczy względów manualnych, przy jednoczesnej poprawie bezpieczeństwa prowadzonych badań diagnostycznych. Niestety, fibroskopy optyczne mają również wady. Oprócz nieznacznie obniżonej jakości obrazu, w stosunku do boroskopu, są one bardzo wrażliwe na nadmierne, trwałe i gwałtowne manewrowanie sondą wziernikową. Powoduje to pękanie włókien szklanych, które objawia się czarnymi kropkami na obserwowanym obrazie (rys. 4). Co ciekawe, wraz z wiekiem obniża się elastyczność wiązki światłowodowej i wyraźnie skraca się czas ,życia” jej włókien. Należy zaznaczyć, że pęknięcie pojedynczego włókna światłowodu jest zjawiskiem nieuniknionym w eksploatacji fibroskopu. Jest ono dopuszczalne nawet $\mathrm{w}$ fazie produkcji nowego urządzenia, jednak wówczas sumaryczna liczba pękniętych 
dimensions of the detected defects. The observed size is a function not only of the real dimensions of the defect but also of the distance of the lens from the examined surface. Since the machine manufacturers provide the admissible values related to surface defects of the most susceptible constructional elements the identification of the actual dimensions of the defect is a key diagnostic issue. włókien w wiązce światłowodowej nie może przekraczać 1 promila [6].

Nową erę endoskopii otworzyła współczesna optoelektronika i technika cyfrowa, co zaowocowało skonstruowaniem w 1983 r. wideoskopu (rys. 5). Jest to endoskop cyfrowy, w którym, zachowując elastyczność sondy i możliwość zdalnego sterowania końcówką wziernikową, dla przesyłania obrazu wiązkę światłowodową obrazowodu zastąpiono miniaturową kamerą cyfrową umieszczoną w końcówce sondy wziernikowej (w miejsce obiektywu), pozostawiając przy tym światłowodowy układ doprowadzania strumienia świetlnego. Kamera CCD przetwarza obraz optyczny na elektroniczny, który w zapisie cyfrowym transmitowany jest sondą (szyną transmisyjną) na monitor kolorowy LCD. Takie rozwiązanie stwarza nowe możliwości diagnostyczne, włączając możliwość dokonania ilościowej oceny stopnia degradacji badanych powierzchni (możliwość pomiaru wykrytych zmian strukturalnych - defektów, odbarwień, kontrastu itd. Równie istotną zaletą jest uzyskanie wysokiej rozdzielczości obrazu, rzędu kilkuset tysięcy pixeli, która zapewnia jego wyrazistość, nawet przy

b)
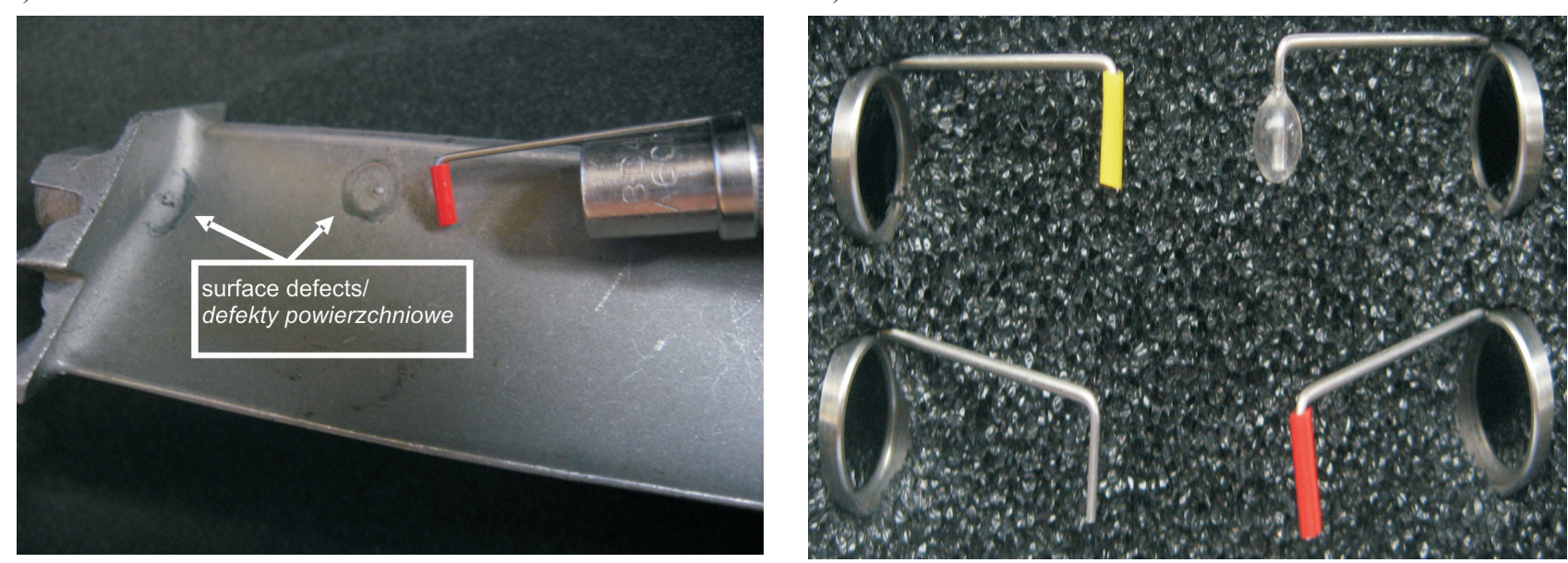

Fig. 6. A comparative fibroscopic measurement of surface defects of a turbine engine vane: a) end of the fibroscope fitted with a calibrated reference frame, b) a set of calibrated reference frames

Rys. 6. Pomiar porównawczy defektów powierzchniowych łopatki silnika turbinowego fibroskopem optycznym: a) widok końcówki sondy wziernikowej fibroskopu wyposażonej w kalibrowanq ksztaltke pomiarowa, b) komplet kalibrowanych ksztaltek pomiarowych

The traditional optical approach provides a comparison which is a calibrated reference frame fitted at the end of the fibroscope (Fig. 6) [9].

It is important to select an appropriate lens head to ensure angular constraint of the field of view in the direction ahead - Fig. 7a or b, or possibly sideways - Fig. 7c. Depending on the distance between the lens and the examined surface the field of view is selected in such a way that it enables a maximum enhancement of the examined surface while maintaining the sharpness of the image.

Digital endoscopy brings entirely new possibilities. Digital image analyzers working with Stereo, Laser or Shadow measurement heads, based on the theory of triangulation are capable of precise determination of the distance of the lens słabo oświetlonej powierzchni. Zapis cyfrowy obrazu, jako wideoinformacja w formacie np. JPEG, może być przesyłany na znaczne odległości w sieci komórkowej, bądź internetowej. Pozwala to na prowadzenie wielostronnej konsultacji specjalistycznej, wspierającej proces wnioskowania diagnostycznego, bądź konsultacji dydaktycznych mających na celu szkolenie i wymianę doświadczeń.

\section{Metody pomiarowe stosowane $w$ endoskopii cyfrowej}

Podczas oglądu przez endoskop optyczny powierzchni ograniczających przestrzenie wewnętrzne maszyny często brakuje wzorców odniesienia, które można wykorzystać do określenia wymiarów wykrytych defektów. Obserwowany 
from the examined surface, hence they determine the dimensions of the surface defects. The measurement heads enable a digital processing of the stereoscopic effects which allows the images to give the impression of three-dimensional space (focus depth, layout, solidness).

\subsection{Stereo method}

The basis of the Stereo method (Fig. 8) is proper utilization of the properties of a prism dispersing the image, which enables a digital camera to record it from two points limited by the spacing of the parallactic lens, analogically to human brain receiving information about the surroundings from a pair of eyes spaced a few centimeters from one another ( $65 \mathrm{~mm}$ base) [3]. The images received from the parallactic lens differ from each other and the effect of the realization of the calculation algorithm is the resultant image on a high resolution LCD display. The distance of the lens form the examined surface is determined through counting of the pixels in the horizontal plane of the display between the analogical points of the left and right view of the observed element. The larger the distance from the observed surface the larger the distance between the cursor of the left and right view on the display - Fig. 9.

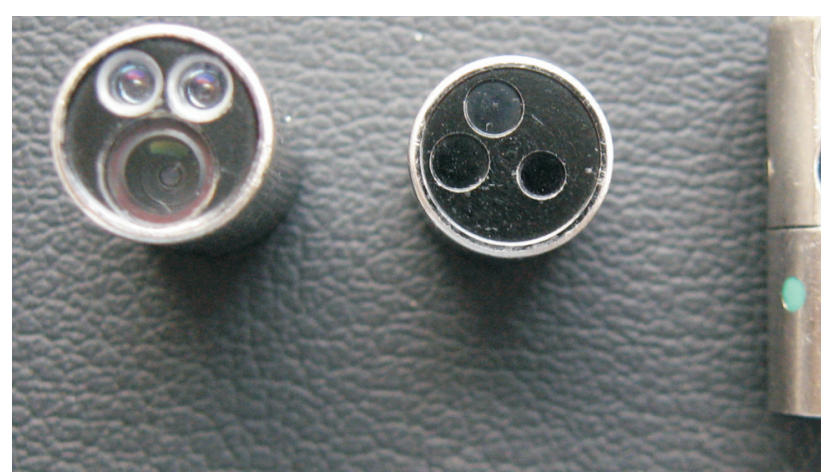

Fig. 7. Replaceable heads fitted on the end of the fribroscope: a) direction of viewing - ahead, view angle 80 degrees, b) direction of viewing - ahead, view angle 60 degrees, c) direction of viewing - sideways, view angle 80 degrees

Rys. 7. Wymienne głowiczki obiektywowe nakładane na końcówkę sondy wziernikowej: a) kierunek obserwacji na wprost, kat pola widzenia 80 stopni, b) kierunek obserwacji na wprost, kat pola widzenia 60 stopni, c) kierunek obserwacji boczny, kat pola widzenia 80 stopni

In the subsequent stage of the measurement technology the technique has to be selected. The following metrological options of the digital measurement realization using the Stereo method available with top manufacturers OLYMPUS and EVEREST [7, 12, 14] are known:

- length,

- multi-segment length, broken line length (circumference),

- distance of the point from the base straight line,

- depth (protrusion), - area.

In each metrological option the accuracy of measurement is determined, which can reach $95-98 \%[12,14]$ assuming the operator's high level of expertise. wymiar jest funkcją nie tylko rzeczywistego wymiaru defektu, ale również odległości obiektywu sondy wziernikowej od badanej powierzchni. Ponieważ producenci maszyn podają dopuszczalne wartości defektów powierzchniowych najbardziej newralgicznych elementów konstrukcyjnych, określenie rzeczywistych wymiarów defektu jest kluczowym zagadnieniem diagnostycznym.

W tradycyjnym, optycznym podejściu do tego zagadnienia stosuje się metodę porównawczą, wykorzystując do tego celu kalibrowane kształtki pomiarowe nakładane na końcówkę sondy wziernikowej fibroskopu - rys. 6 [9].

Należy przy tym dobrać odpowiednią głowiczkę obiektywową, która zapewni optymalne kątowe ograniczenie pola widzenia w kierunku obserwacji na wprost - rys. 7a lub b, ewentualnie w kierunku obserwacji bocznym - rys. 7c. W zależności od odległości pomiędzy obiektywem i badaną powierzchnią dobiera się taką szerokość pola widzenia, która umożliwi maksymalne powiększenie badanej powierzchni przy zachowaniu wymaganej głębi ostrości (wyrazistości obrazu).

Zupełnie nowe możliwości wnosi w tym względzie endoskopia cyfrowa. Cyfrowe analizatory obrazu, współpracujące z głowicami pomiarowymi typu Stereo, Cień czy Laser, bazujące na teorii triangulacji są w stanie precyzyjnie określić odległość obiektywu sondy wziernikowej od obserwowanej powierzchni, a stąd wyznaczyć wymiary wykrywanych defektów powierzchniowych. Głowice pomiarowe dają możliwość cyfrowego przetwarzania efektów stereoskopowych, co pozwala zwymiarować widziane obrazy w taki sposób, aby dawały wrażenie quasi-trójwymiarowości z ich głębią, bryłowatością i wzajemnym rozmieszczeniem.

\subsection{Metoda Stereo}

Podstawą metody Stereo (rys. 8) jest odpowiednie wykorzystanie właściwości pryzmatu rozszczepiającego obraz, co umożliwia kamerze cyfrowej jego rejestrację z dwóch punktów ograniczonych rozstawem soczewek paralaktycznych, analogicznie do mózgu ludzkiego, otrzymującego informacje o otaczającym świecie od pary oczu umieszczonych w odległości kilku centymetrów od siebie (jest to tzw. baza oczna wynosząca około $65 \mathrm{~mm}$ ) [3]. Obrazy przekazywane z soczewek paralaktycznych różnią się od siebie, a efektem realizacji algorytmu obliczeniowego jest wyznaczenie wypadkowego obrazu cyfrowego na monitorze LCD o wysokiej rozdzielczości. Odległość obiektywu od obserwowanej powierzchni wyznaczana jest przez zliczanie pikseli w płaszczyźnie poziomej monitora komputera pomiędzy analogicznymi punktami lewego i prawego widoku obserwowanego elementu. Im jest większy dystans do obserwowanej powierzchni, tym większa jest odległość pomiędzy kursorami lewego i prawego widoku na ekranie monitora - rys. 9.

W kolejnym etapie technologii pomiaru należy dokonać wyboru techniki pomiarowej. Znane są następujące opcje metrologiczne realizacji pomiaru cyfrowego $\mathrm{w}$ metodzie Stereo oferowane przez czołowych producentów sprzętu endoskopowego, tj. OLYMPUS i EVEREST [7, 12, 14]: - długość,

- długość wielosegmentowa, długość łamanej (obwód), 


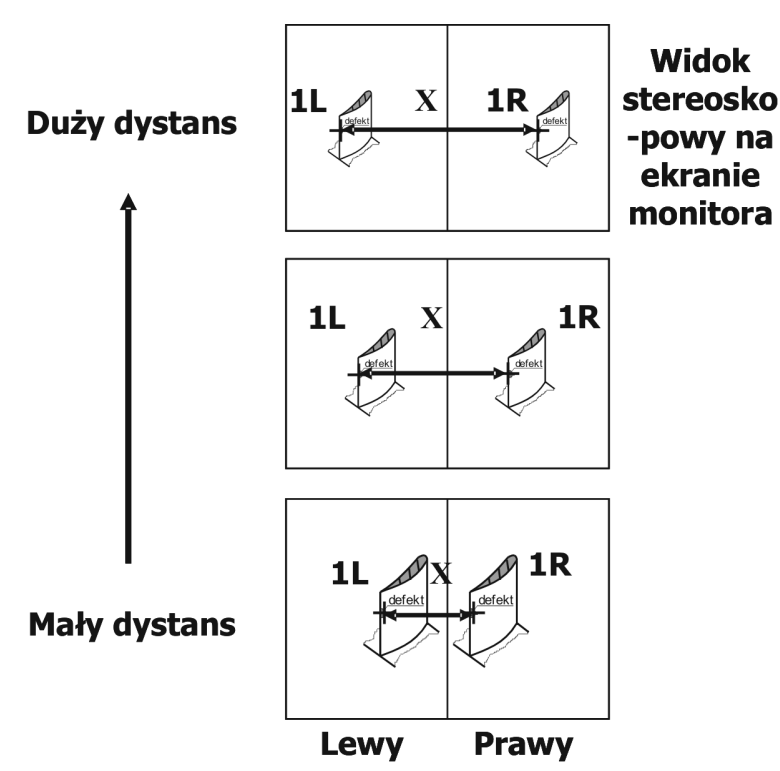

Fig. 9. Stereoscopic view on an LCD display Rys. 9. Widok stereoskopowy na ekranie monitora LCD

Figure 10 shows the recorded results of the endoscopic examinations of the vanes in marine turbine combustion engines conducted by the author of this paper. In order to determine the dimensions of the detected surface defects the Stereo method was applied with the use of a videoscope EVEREST-XL PROTM (courtesy the manufacturer's general distributor in Poland). The presented numerical data show that the key metrological issue is obtaining high accuracy indexes, which guarantees a satisfactory result of the measurement. The accuracy is determined by the magnification of the examined surface and the quality of its illumination i.e. the distance of the end of the endoscope from the examined surface and deviations of its position from the perpendicular. The shorter the distance from the examined defect the higher the accuracy index. A measurement from a distance smaller than $15 \mathrm{~mm}$ ensures the highest accuracy provided that the high level of image sharpness is maintained. As we can see only in cases a and $\mathrm{c}$ the result of the measurement is satisfactory, which validates the importance of the diagnostic technician's expertise.

\subsection{Shadow method}

Another field where the triangulation method in digital endoscopy is applied to determine the dimensions of the surface defects is the shadow method-Fig. 11. The speculum is fitted with a specialized optics generating a shadow (projector) of a characteristic shape (most frequently a straight line) on the examined surface. The shadow projection is performed while the angle of the speculum position against the observed surface and the angle of observation sector is known. A shadow generated near the defect is localized and recorded by a CCD camera placed in the head. The closer is the head to the examined surface the closer is the shadow line to the left side of the display. Since we know the position of the shadow generating the image on the display we can easily calculate the enhancement of this image, hence determine the

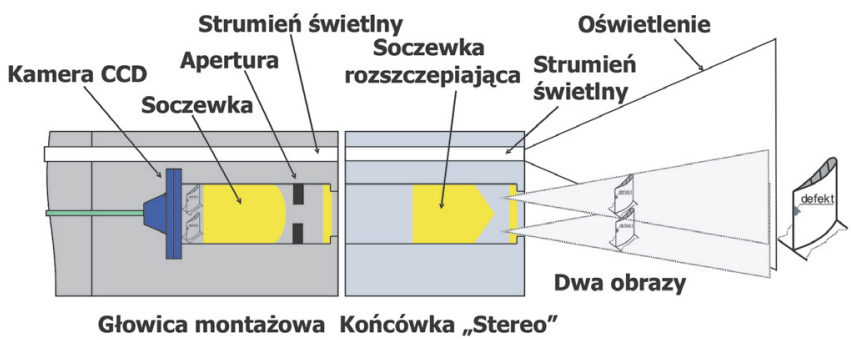

Fig. 8. Schematics of the Stereo measurement method [14]

Rys. 8. Schemat ideowy metody pomiarowej Stereo [14]

- odległość punktu od prostej bazowej

- głębokość (wypukłość),

- pole powierzchni (obszar).

W każdej opcji metrologicznej określa się dokładność pomiaru, która przy wysokiej wprawności operatora sięgać może 95-98\% [12, 14].

Na rysunku 10 przedstawiono zarejestrowane wyniki badań endoskopowych łopatek wirnikowych okrętowych turbinowych silników spalinowych, przeprowadzonych przez autora niniejszego artykułu. Do określenia wymiarów wykrytych defektów powierzchniowych zastosowano metodę Stereo, przy wykorzystaniu wideoskopu pomiarowego EVEREST typu XL PROTM (dzięki uprzejmości przedstawicieli firmy na Polskę). Z zaprezentowanych danych liczbowych wynika, że kluczowym zagadnieniem metrologicznym jest uzyskanie wysokich wartości indeksów dokładności, co gwarantuje satysfakcjonujący wynik pomiaru. Dokładność pomiaru jest zdeterminowana powiększeniem badanej powierzchni i jakością jej oświetlenia, a wiec odległością końcówki wziernikowej od badanej powierzchni i odchyleń jej położenia od kierunku prostopadłego. Im mniejszy jest dystans do obserwowanego defektu, tym wyższe wartości przyjmuje indeks dokładności. Największą dokładność gwarantuje pomiar dokonywany z odległości mniejszej od $15 \mathrm{~mm}$, pod warunkiem utrzymania dużej głębi ostrości rejestrowanego obrazu. Jak widać, tylko w przypadku a i c wynik pomiaru uznać można za zadowalający, co potwierdza kluczową rolę doświadczeń manualnych operatora (diagnosty).

\subsection{Metoda Cienia}

Innym obszarem zastosowania teorii triangulacji do wyznaczania wymiarów defektów powierzchniowych jest stosowana w endoskopii cyfrowej metoda Cienia - rys. 11. Końcówka głowicy wziernikowej wideoskopu wyposażona jest w specjalistyczną optykę generującą w strumieniu świetlnym (jak projektor) na powierzchnię badanego elementu cień o charakterystycznym kształcie (najczęściej linii prostej). Projekcja cienia odbywa się przy znanym kącie położenia głowicy wziernikowej w stosunku do obserwowanej powierzchni i znanym kącie sektora obserwacji. Cień generowany w pobliże wykrytego defektu jest następnie lokalizowany i rejestrowany przez kamerę CCD umieszczoną w głowicy montażowej. Im bliżej obserwowanej powierzchni znajduje się głowica wziernikowa, tym bliżej lewej strony ekranu monitora znajduje się linia cienia. Ponieważ znane 


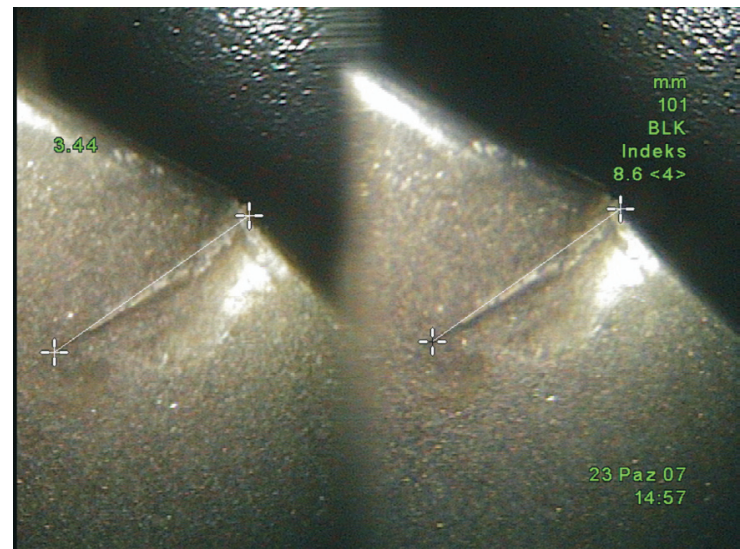

a) measurement of the length of indentation on vane edge $-3.44 \mathrm{~mm}$, with accuracy index 8.6, which corresponds to $0.2 \mathrm{~mm}$

a) pomiar długości wgniecenia na krawędzi splywu topatki-3,44 mm, przy indeksie dokładności pomiaru 8,6, co odpowiada $0,2 \mathrm{~mm}$

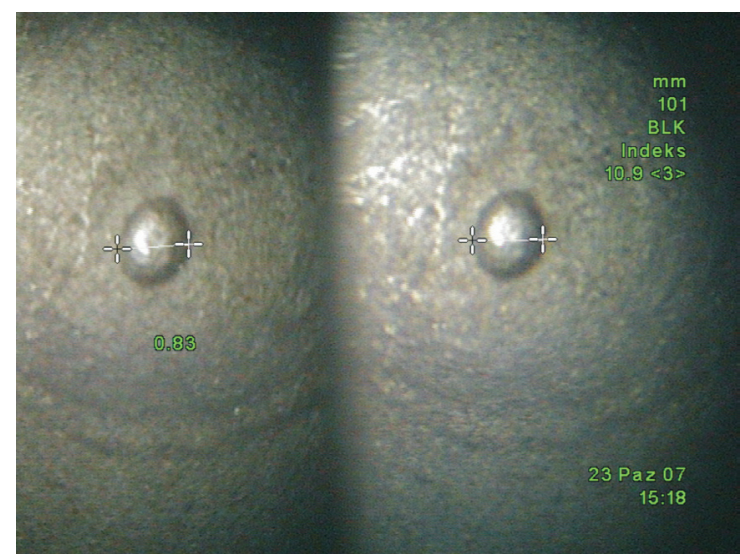

c) measurement of the diameter of the bulge on vane surface $-0.83 \mathrm{~mm}$, with accuracy index 10.9 , which corresponds to $0.1 \mathrm{~mm}$

c) pomiar średnicy "wyprysku" powierzchniowego w korycie topatki - 0,83 mm, przy indeksie dokładności pomiaru 10,9, co odpowiada 0,1 mm

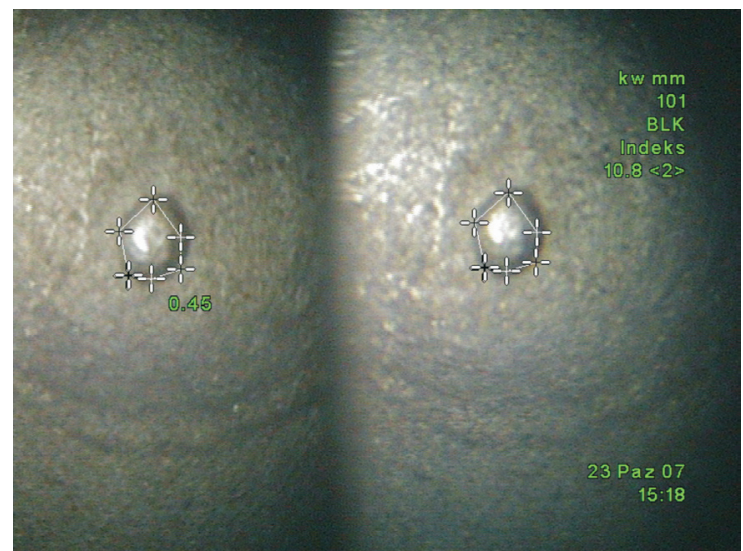

e) measurement of the area of the envelope (closed broken line) of the bulge on vane surface $-0.45 \mathrm{~mm}^{2}$, with accuracy index 10.8 , which corresponds to $0.1 \mathrm{~mm}^{2}$

e) pomiar pola powierzchni obwiedni (tamana zamknięta) "wyprysku" powierzchniowego w korycie topatki-0,45 $\mathrm{mm}^{2}$, przy indeksie dokładności pomiaru 10,8, co odpowiada $0,1 \mathrm{~mm}^{2}$

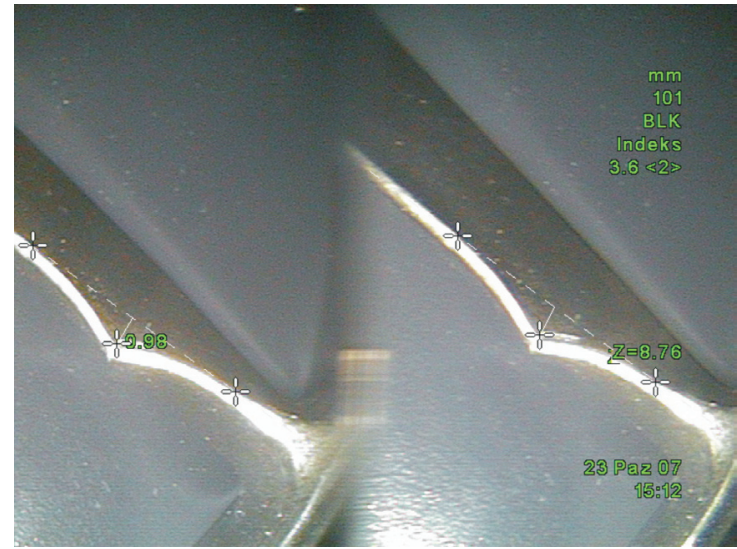

b) measurement of the length of indentation on vane edge point-straight method $-0.98 \mathrm{~mm}$, with accuracy index 3.6, which corresponds to $0.5 \mathrm{~mm}$ b) pomiar głębokości wgniecenia na krawędzi spływu łopatki metoda ,,punktprosta" - 0,98 mm, przy indeksie doktadności pomiaru 3,6, co stanowi 0,5 m

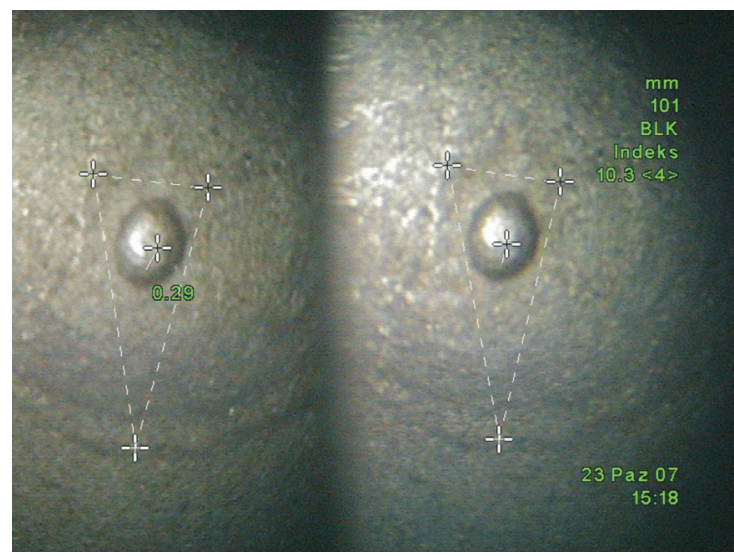

d) measurement of the surface protrusion of the bulge on vane surface $-0.29 \mathrm{~mm}$, with accuracy index 10.3 , which corresponds to $0.1 \mathrm{~mm}$ d) pomiar wypuktości "wyprysku" powierzchniowego w korycie topatki - 0,29 mm, przy indeksie doktadności pomiaru 10,3, co odpowiada 0,1 mm

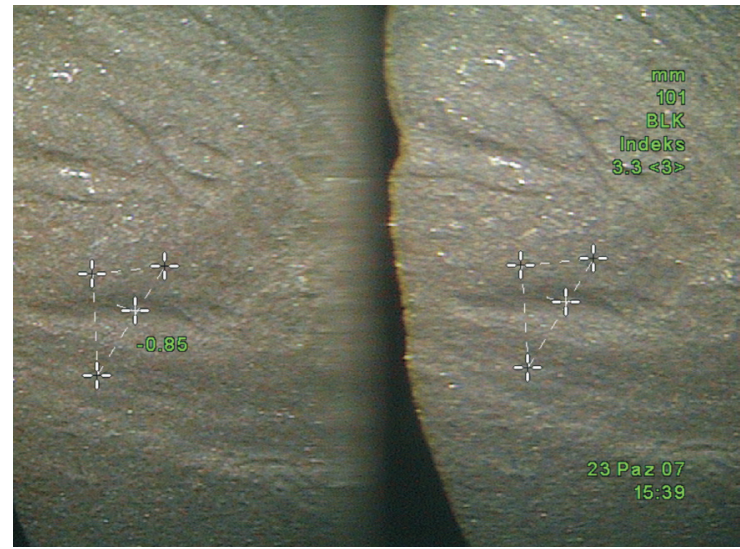

f) measurement of the depth of the surface attrition on vane surface $-0.85 \mathrm{~mm}$, with accuracy index 3.3 , which corresponds to $0.7 \mathrm{~mm}$

f) pomiar głębokości ubytku powierzchniowego w korycie topatki - 0,85 mm, przy indeksie dokładności pomiaru 3,3, co odpowiada $0,7 \mathrm{~mm}$

Fig. 10. The results of measurements of surface defects on vanes of marine turbine combustion engines with the use of the Stereo method

Rys. 10. Wyniki pomiaru defektów powierzchniowych na topatkach wirnikowych okrętowych turbinowych silników spalinowych z wykorzystaniem metody Stereo 


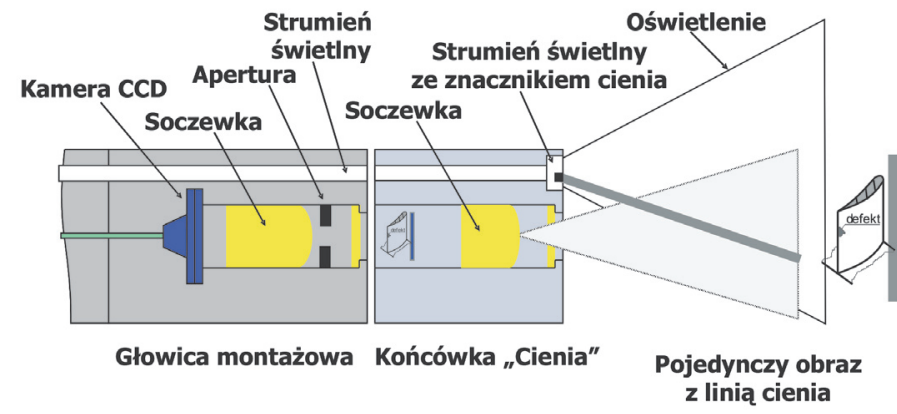

Fig. 11. Schematics of the shadow method [14]

Rys. 11. Schemat ideowy metody pomiarowej Cienia [14]

linear distance between individual pixels and then the real dimensions of the surface defects - Fig. 12 and 13.

The technician confirms the position of the shadow line on the display matrix by putting a cursor line on the shadow (dotted line Fig. 12a). Thus, the digital coordinates of the shadow line are determined e.g. Fig. 12a the digital position of the shadow line on the display matrix corresponds to 150

a)

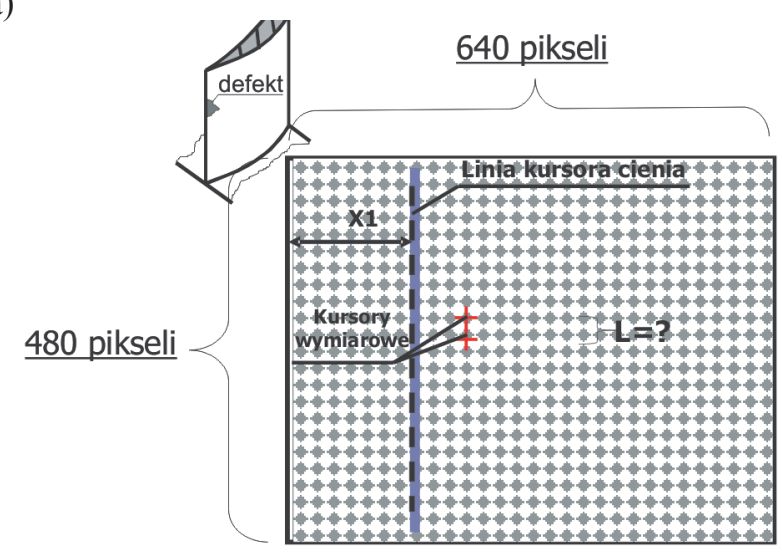

jest położenie cienia generującego obraz na matrycy ekranu monitora LCD, można w prosty sposób wyliczyć powiększenie tego obrazu, a stąd wyznaczyć wymiar liniowy odległości pomiędzy pojedynczymi pikselami, a następnie rzeczywiste wymiary wykrywanych defektów powierzchniowych - rys. 12 i 13 .

Operator potwierdza położenie linii cienia na matrycy monitora przez nałożenie na cień linii kursora (linia przerywana na rys. $12 \mathrm{a}$ ). W ten sposób ustalane są cyfrowe współrzędne linii cienia, np. na rys. 12a cyfrowe położenie linii cienia na matrycy monitora odpowiada 150 pikselom liczonym od lewej strony ekranu. Z danych kalibracyjnych zastosowanej głowicy pomiarowej przechowywanej w komputerowej bazie danych wideoskopu wynika, że odpowiada to odległości obiektywu od obserwowanej powierzchni wynoszącej (przykładowo) $20 \mathrm{~mm}$.

Algorytm obliczeniowy komputera, wykorzystując proste zależności trygonometryczne, wyznacza współrzędną X1 na matrycy monitora - rys. 13, z zależności (1), stąd wymiar W określony jest za pomocą równania (2). b)

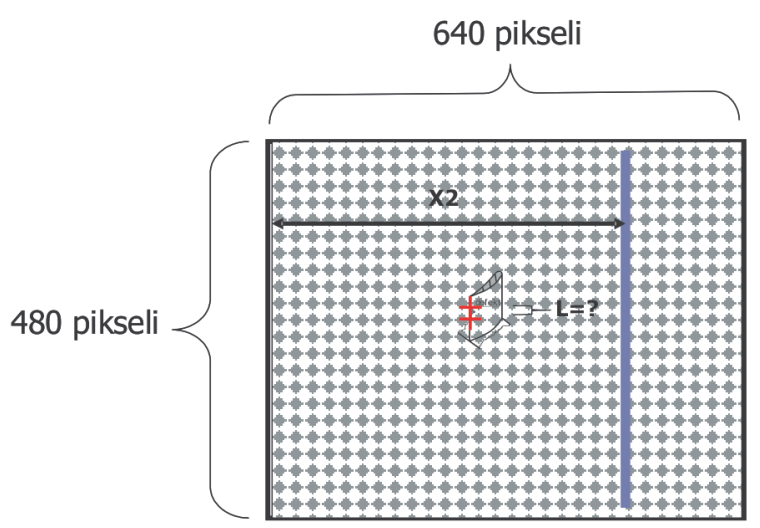

Fig. 12. Display unit matrix in the shadow method [14]: a) small distance from the object, high magnification, shadow to the left of the object, b) large distance from the object, low magnification, shadow to the right of the object

Rys. 12. Widok matrycy ekranu monitora LCD w metodzie Cienia [14]: a) maty dystans do obiektu, duże powiększenie, cień po lewej stronie obiektu, b) duży dystans do obiektu, małe powiększenie, cień po prawej stronie obiektu

pixels counted from the left of the display. From the calibration data of the measurement head stored in the videoscope database we know that this corresponds to the distance of the lens $20 \mathrm{~mm}$ from the observed surface.

The computer algorithm, using simple trigonometric dependences, determines the coordinate $\mathrm{X} 1$ on the display matrix - Fig. 13, from the dependence:

$$
\mathrm{X} 1=\operatorname{tg} \alpha \cdot 20 \mathrm{~mm}=\operatorname{tg} 25^{\circ} \cdot 20 \mathrm{~mm}=9.32 \mathrm{~mm}
$$
hence, dimension $\mathrm{W}$ is:

$$
\mathrm{W}=2 \cdot 3.32 \mathrm{~mm}=18.64 \mathrm{~mm}
$$

For a given resolution of the display matrix -640 pixels against $\mathrm{X}$ which corresponds to $18.64 \mathrm{~mm}$ we can determine (from the proportions) the distance between the individual pixels of $0.029 \mathrm{~mm}$. Hence, the actual dimensions of the defect L as the distance between the cursors (Fig. 12a) is calculated by multiplying the conversion coefficient 0.029 $\mathrm{mm} /$ pixel by the number of pixels between the cursors mar-
Dla danej rozdzielczości matrycy monitora LCD wynoszącej względem X - 640 pikseli, co odpowiada wymiarowi 18,64 mm można określić (z proporcji) odległość pomiędzy pojedynczymi pikselami wynoszącą 0,029 $\mathrm{mm}$. A zatem rzeczywisty wymiar wykrytego defektu L, jako odległość pomiędzy kursorami wymiarowymi (rys. 12a), oblicza się, mnożąc współczynnik przeliczeniowy $0,029 \mathrm{~mm} /$ piksel przez liczbę pikseli pomiędzy kursorami wymiarowymi zaznaczonymi przez operatora (współrzędne pionowe i poziome) odczytaną przez komputer $\mathrm{z}$ matrycy monitora.

W metodzie Cienia dostępne są następujące opcje pomiarowe:

- długość,

- długość skośna,

- długość wielosegmentowa, długość łamanej (obwód),

- odległość punktu od prostej bazowej, 
ked by the technician (vertical and horizontal coordinates) and read by the computer for the display matrix.

In the shadow method the following options are available:

- length,

- skew length,

- multi-segment length, broken line length (circumference),

- distance of the point from the base straight line,

- depth (protrusion),

- diameter of the marked area (taken by a gauge).

Figure 14 shows the recorded results of the endoscopic examinations of the same turbine vanes of marine combustion engines that were previously examined by the stereo method. This time the shadow method was applied for the detection of the surface defects.

A very strong advantage of the shadow method is the possibility of precise interpretation of whether we see an attrition or a deposit. Such diagnostic problems occur in the examination of internal parts of piston or turbine combustion engines. Very frequently, due to optical and illuminative effects a simple foul of the surface of the air or exhaust flow channels (mineral deposits or products of fuel combustion - carbon) is interpreted as a corrosive or erosive attrition of the material. As we can see in Fig. 15a these doubts can be cleared by the nature of the deformation of the shadow line. If the surface is indented (larger distance from the head) the shadow line is refracted and shifted to the right on the display, if it is bulged (closer to the head) refraction and a shift to the left on the display occurs. Figure $15 \mathrm{~b}$ shows an example result of a depth measurement of a concave profile taken by EVEREST XL PROTM. On the display we can see the result $-1.65 \mathrm{~mm}$ at accuracy index 10.1, which corresponds to $0.25 \mathrm{~mm}$.

The shadow method is characterized by its utilitarian values, which is confirmed by the diagnostic tests on marine engines and a very high accuracy that may reach up to $95 \%$ if proper diagnostic conditions are maintained [14]. The most important elements conditioning the high measurement accuracy is the maximum proximity of the head and the examined surface (the shadow line is shifted to the left as the head approaches the surface) and keeping the head in a position perpendicular to the surface (the shadow line goes perpendicularly to the base of the display).

\subsection{Laser method}

The laser method is the youngest measurement technology in digital endoscopy. In technical diagnostics two ways of using laser beams are known for measuring surface defects of elements of industrial machinery. The first one is the multipoint laser method, patented by KARL STORZ GmbH \& Co. KG - Fig. 16 [13]. The idea behind this measurement is to determine the distance of the examined surface from the head of the endoscope through a base surface composed of at least 3 (out of 49) best fitted marker matrix laser points,

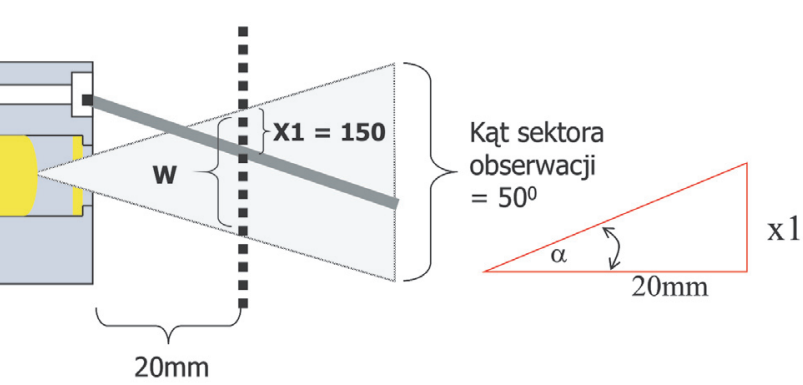

Fig. 13. Schematics of the shadow method [14]

Rys. 13. Schemat ideowy metody Cienia [14]

- głębokość (wypukłość),

- średnica zaznaczonego obszaru (przez przymiar kołowy).

$\mathrm{Na}$ rysunku 14 przedstawiono zarejestrowane wyniki badań endoskopowych tych samych łopatek wirnikowych okrętowych turbinowych silników spalinowych, które wcześniej poddano analizie wymiarowej z wykorzystaniem metody Stereo. Tym razem do określenia wymiarów wykrytych defektów powierzchniowych zastosowano metodę Cienia.

Bardzo istotną zaletą metody Cienia jest możliwość natychmiastowego rozstrzygnięcia wątpliwości odnośnie do właściwej interpretacji (jednoznacznego rozróżnienia) defektów powierzchniowych skutkujących ubytkiem bądź nawarstwieniem materiału. Tego typu problemy diagnostyczne występują w ocenie stanu technicznego przestrzeni roboczych silników spalinowych: tłokowych bądź turbinowych. Często z powodu efektów optycznych i świetlnych zwykłe zanieczyszczenie powierzchni kanałów przepływowych powietrza lub spalin w postaci osadów mineralnych lub produktów spalania paliwa (nagaru) interpretowane sąjako korozyjne lub erozyjne ubytki materiału konstrukcyjnego. Jak widać na rys. 15a, tego typu wątpliwości rozstrzyga obserwowany na monitorze wideoskopu charakter deformacji linii cienia rzucanego na badaną powierzchnię. Wgłębieniu powierzchni (jej większemu oddaleniu od głowicy wziernikowej) towarzyszy załamanie i przesunięcie linii cienia w prawą stronę ekranu, a jej wypukłości (jej większemu przybliżeniu do głowicy wziernikowej) - załamanie i przesunięcie linii cienia w lewą struną ekranu. Na rysunku 15b przedstawiono przykładowy wynik pomiaru głębokości wklęsłego profilu powierzchniowego dokonanego wideoskopem EVEREST typu XL PROTM. Na ekranie monitora widoczny jest rezultat $-1,65 \mathrm{~mm}$, przy indeksie dokładności pomiaru 10,1 , co odpowiada $0,25 \mathrm{~mm}$.

Metodę Cienia charakteryzują potwierdzone w badaniach diagnostycznych silników okrętowych walory utylitarne, a także bardzo duża dokładność, która przy zachowaniu wymaganych warunków pomiaru osiągać może nawet 95\% [14]. Najistotniejszym czynnikiem dużej dokładności pomiaru jest maksymalne przybliżenie głowicy wziernikowej do badanej powierzchni (linia cienia przesuwa się w lewo w miarę przybliżania do powierzchni głowicy wziernikowej) oraz utrzymanie prostopadłego do tej powierzchni położenia głowicy wziernikowej (linia cienia przebiega prostopadle do podstawy ekranu monitora). 


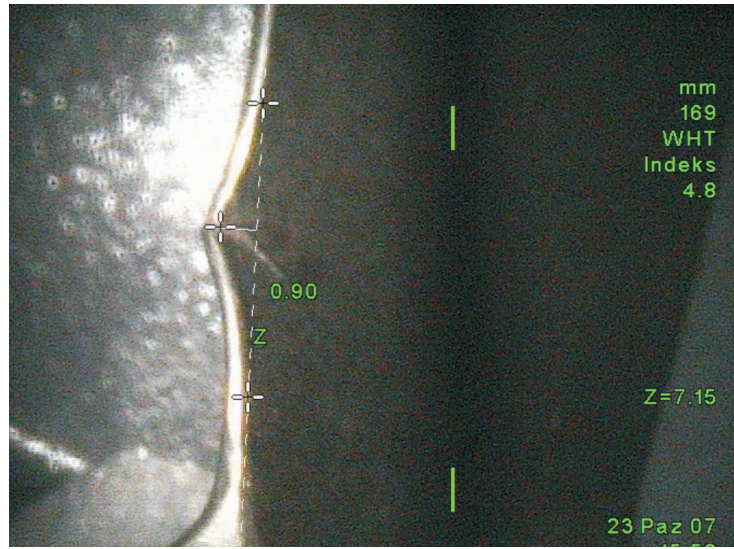

a) measurement of the depth of the indentation on vane edge by point straight method $-0.90 \mathrm{~mm}$, with accuracy index 4.8 , which corresponds to $0.25 \mathrm{~mm}$

a) pomiar głębokości wgniecenia na krawędzi spływu topatki metoda ,,punktprosta" - 0,90 mm, przy indeksie dokładności pomiaru 4,8, co stanowi 0,25 mm

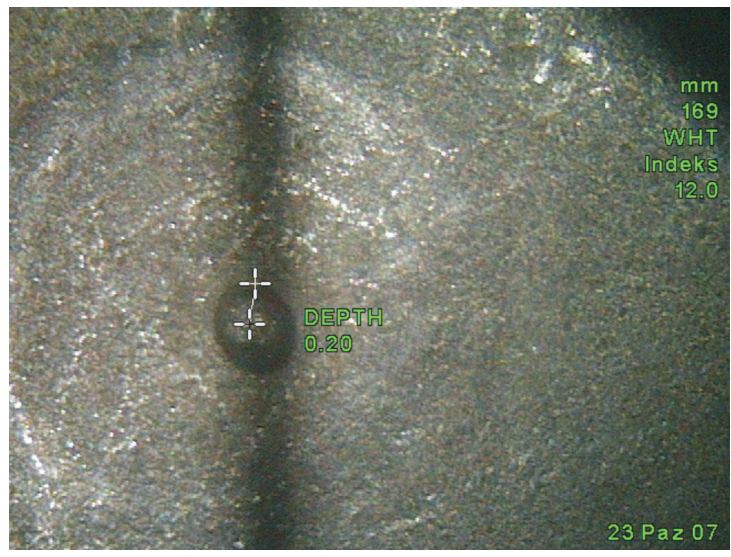

c) measurement of protrusion of the bulge on vane surface $-0.20 \mathrm{~mm}$, with accuracy index 12.0, which corresponds to $0.15 \mathrm{~mm}$

c) pomiar wypuklości "wyprysku" powierzchniowego w korycie topatki - 0,20 mm, przy indeksie dokładności pomiaru 12,0, co odpowiada 0,15 mm

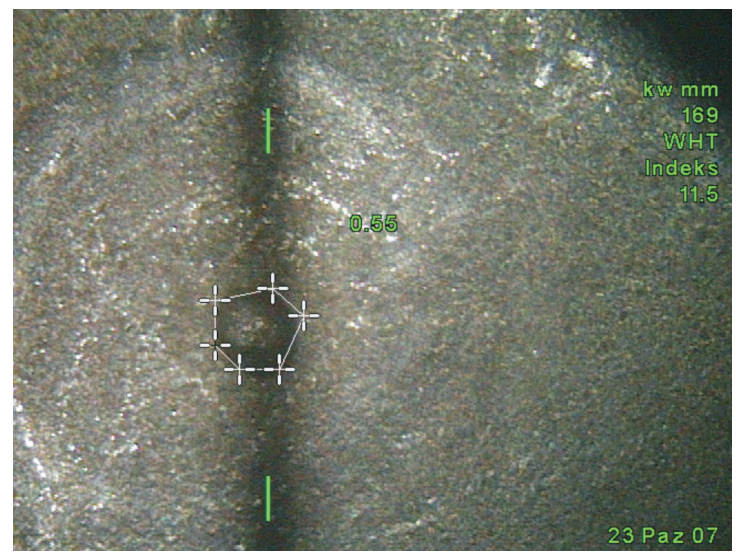

e) measurement of the area of envelope (closed broken line) of the bulge on vane surface and vane edge $-0.55 \mathrm{~mm}^{2}$, with accuracy index 11.5 , which corresponds to $0.1 \mathrm{~mm}^{2}$

e) pomiar pola powierzchni obwiedni (tamana zamknięta) "wyprysku" powierzchniowego w korycie topatki i splywu topatki-0,55 $\mathrm{mm}^{2}$, przy indeksie dokładności pomiaru 11,5, co stanowi $0,1 \mathrm{~mm}^{2}$

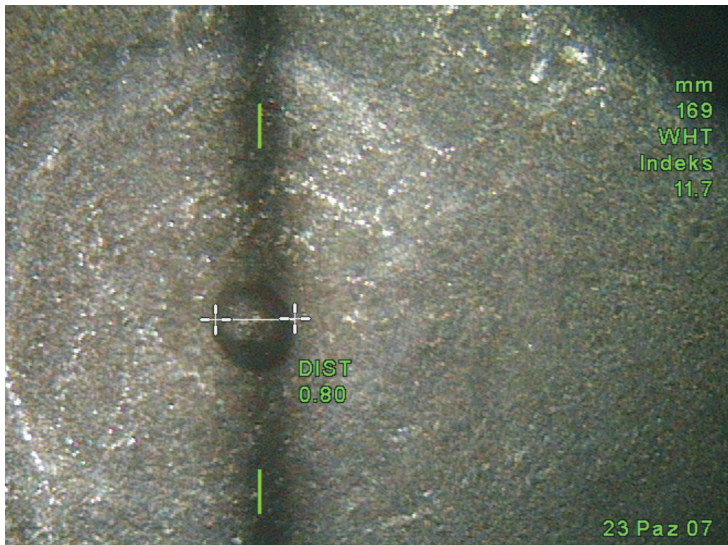

b) measurement of the diameter of the bulge on the surface of the vane $-0.80 \mathrm{~mm}$, with accuracy index 11.7, which corresponds to $0.2 \mathrm{~mm}$

b) pomiar średnicy "wyprysku" powierzchniowego w korycie topatki - 0,80 mm, przy indeksie dokładności pomiaru 11,7, co odpowiada 0,2 mm

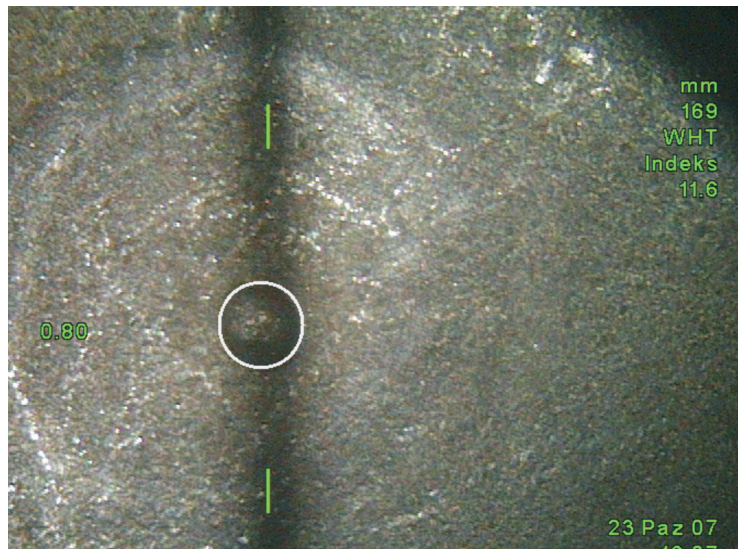

d) measurement of diameter of the bulge with a gauge $-0.80 \mathrm{~mm}$, with accuracy index 11.6, which corresponds to $0.1 \mathrm{~mm}$

d) pomiar średnicy "wyprysku" powierzchniowego przymiarem kolowym - 0,80 mm, przy indeksie dokładności pomiaru 11,6, co odpowiada 0,1 mm

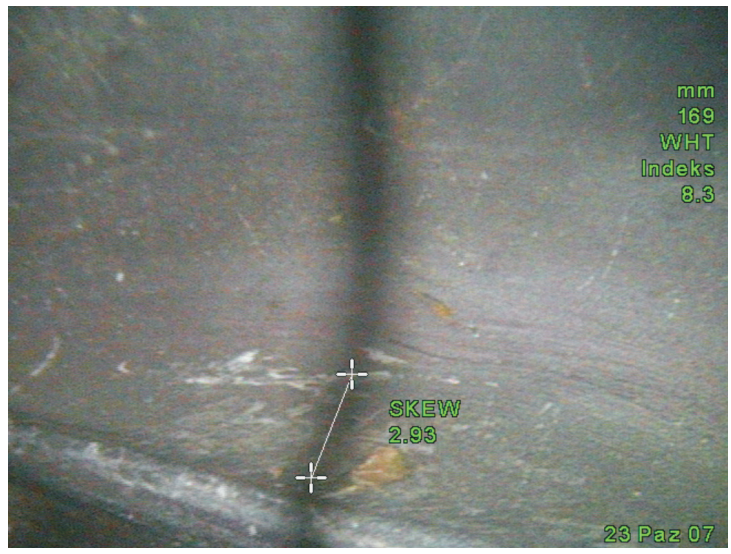

f) measurement of length of the indentation profile of the vane on the edge $-2.93 \mathrm{~mm}$, with accuracy index 8.3 , which corresponds to $0.1 \mathrm{~mm}$

f) pomiar dlugości profilu wgtębienia koryta topatki przy krawędzi natarcia-2,93 mm, przy indeksie doktadności pomiaru 8,3, co odpowiada $0,1 \mathrm{~mm}$

Fig. 14. The results of the measurements of the surface defects on the vanes of marine turbine combustion engines with the use of the shadow method Rys. 14. Wyniki pomiaru defektów powierzchniowych na topatkach okrętowych turbinowych silników spalinowych z wykorzystaniem metody Cienia 
a)

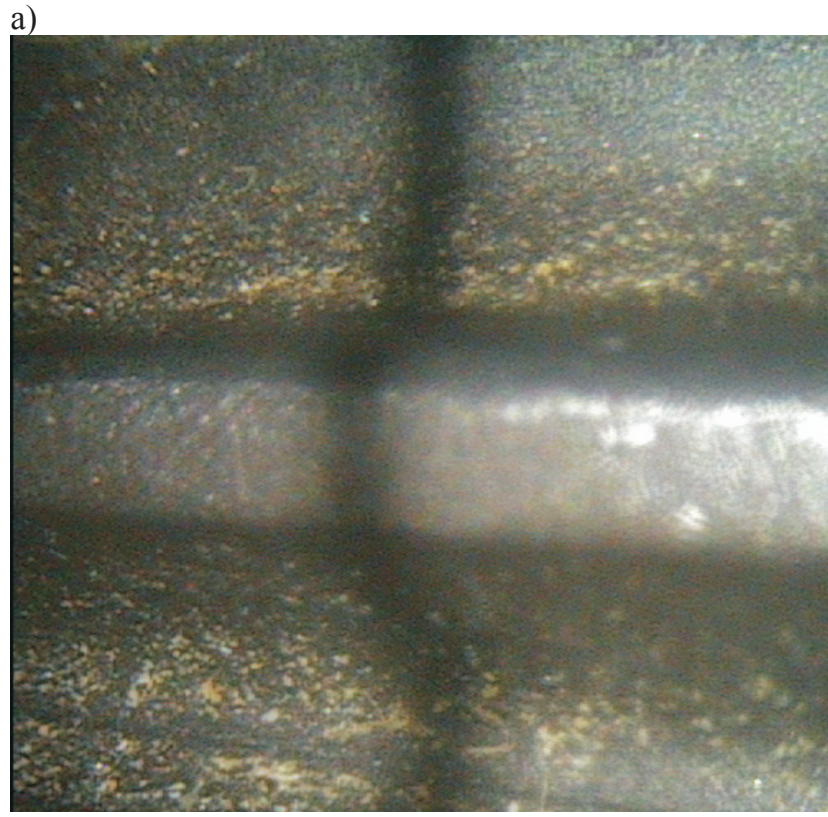

b)

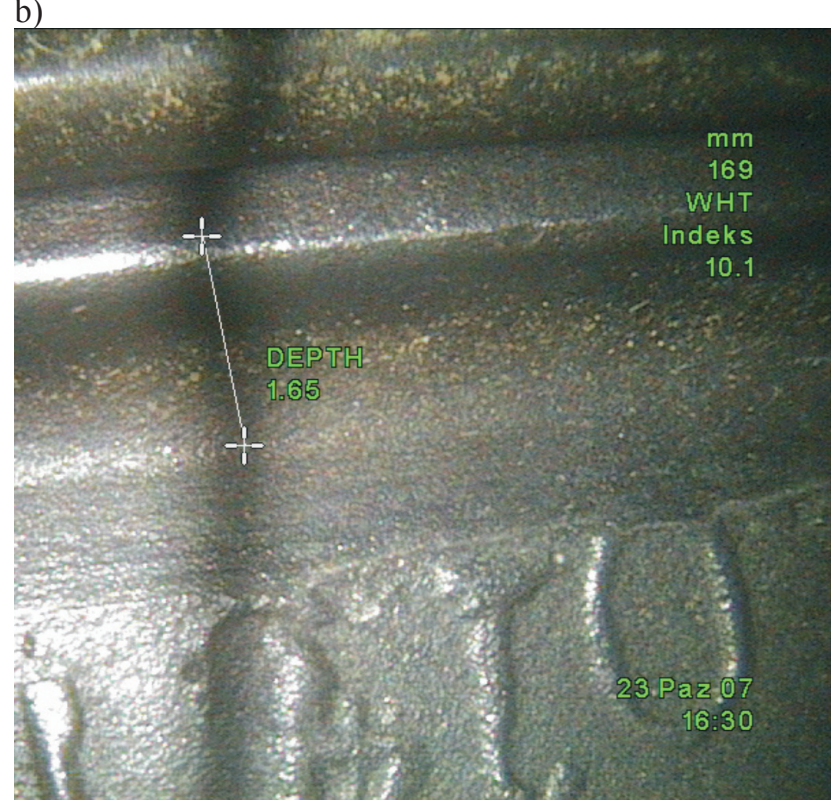

Fig. 15. Measurements of the surface defects with the use of the shadow method: a) deformations of the shadow lines on the indentations and bulges of the examined surface, b) measurement of the depth of the concave surface

Rys. 15. Pomiary nierówności powierzchniowych z wykorzystaniem metody Cienia: a) deformacje linii cienia na wgłębieniach i wypukłościach badanej powierzchni, b) pomiar głębokości wklęsłego profilu powierzchniowego

projected on the observed element from a dispersing optical unit. The shorter the distance to the examined surface the larger the shift of the laser markers to the left of the display. In the next stage of the measurement the image of the surface is recorded (still image) and then, through triangulation, the dimensions of the defect is determined (similarly to OLYMPUS and EVEREST): length, depth (protrusion), area, distance from the point from the base straight line - Fig. 16b.

Another way to use laser for surface defect measurement is scanning patented by REMOTE VISION SOLUTIONS Pty LtdFig. 17 [8]. It is used, but not limited to, the Boeing service teams to search for defects in the plane fuselage. The optical system of a laser scanner disperses the laser beams in a set of rotating mirrors. The dispersed laser beam cast on the examined surface is reflected onto a converging lens and a measuring detector. The amount of the reflected light depends on the condition of the surface. If the scanning beams reflects from a defected surface absorption of light will take place resulting from a lower amount of reflected light. As a consequence the intensity of the reflected light (the concentration of the light on the converging lens) is lower than in the case of a defect free surface. The dimensional assessment of the defective elements is performed based on spectral analysis of the dispersed laser beam in a computer analyzing software - Fig. 17b. The application of cylindrical optics in the laser scanning system considerably extends its range of application (the laser beam is dispersed into a continuous circumference line) enabling to assess smaller surfaces e.g. the internal parts of piston engines particularly inside a cylinder.

\subsection{RGB method}

A digital image stored in the videoscope computer is composed of different elements i.e. pixels each of which is specified as a group of red green and blue image components.

\subsection{Metoda laserowa}

Metoda laserowa jest najmłodszą technologią pomiarową stosowaną $\mathrm{w}$ endoskopii cyfrowej. W diagnostyce technicznej znane są dwa sposoby wykorzystania promieni laserowych do pomiaru defektów powierzchniowych elementów maszyn i urządzeń przemysłowych. Pierwszy to tzw. znacznikowa (wielopunktowa) metoda laserowa, opatentowana przez niemiecki koncern KARL STORZ GmbH \& Co. $\mathrm{KG}$ - rys. 16 [13]. Istotą pomiaru wielopunktowgo jest wyznaczenie odległości głowicy wziernikowej wideoskopu od badanej powierzchni (powiększenia rzeczywistego obrazu) na podstawie płaszczyzny bazowej utworzonej z co najmniej 3 najlepiej dopasowanych (spośród 49) punktów laserowych matrycy znaczników, rzucanych na obserwowany element z rozpraszającego układu optycznego sondy pomiarowej. Im mniejszy jest dystans do badanej powierzchni, tym większe jest przesunięcie znaczników laserowych w lewą stronę ekranu monitora. W kolejnym etapie realizacji pomiaru rejestrowany jest obraz powierzchni (stop-klatka), a następnie z wykorzystaniem teorii triangulacji, wyznaczane są wymiary wykrytego defektu, w następujących opcjach (podobnie jak w systemach pomiarowych OLYMPUS i EVEREST): długość, głębokość (wypukłość), obszar, odległość punktu od prostej bazowej - rys. 16b.

Drugim sposobem wykorzystania promieni laserowych do pomiaru defektów powierzchniowych jest metoda skaningowa opatentowana przez australijską firmę REMOTE VISION SOLUTIONS Pty Ltd - rys. 17 [8]. Jest ona między innymi stosowana przez grupy serwisowe Boeinga do poszukiwania defektów powierzchniowych na kadłubie samolotu. Układ optyczny skanera laserowego dokonuje transformacji (rozproszenia) promienia laserowego w układzie wirujących 
This format is called RGB. Their appropriate mixing generates all other hues. Each of the RGB hues is characterized by shade, brightness, saturation and clearness. It should be noted that a color, as a unique property of material objects discerned through the sense of vision depends on their physical and chemical structure, the manner of absorbing and reflecting light, the nature of the light itself, ambient air properties and the local specificity (light reflexes). Taking the characteristic features of colors into consideration, we can, in a simple way, perform a spectral analysis of the color composite of the recorded image of the examined surface and, thus, assess its structure. Since some surface defects (changes of physical properties of materials) are characterized by a strictly defined spectral pattern, through comparative spectral analysis we can discern unfavorable changes in the material structure in the early phase of their development. The analyses of the properties of the spectral image on the hue boundaries (sharpness, brightness, surface density) may provide additional diagnostic information.

a)

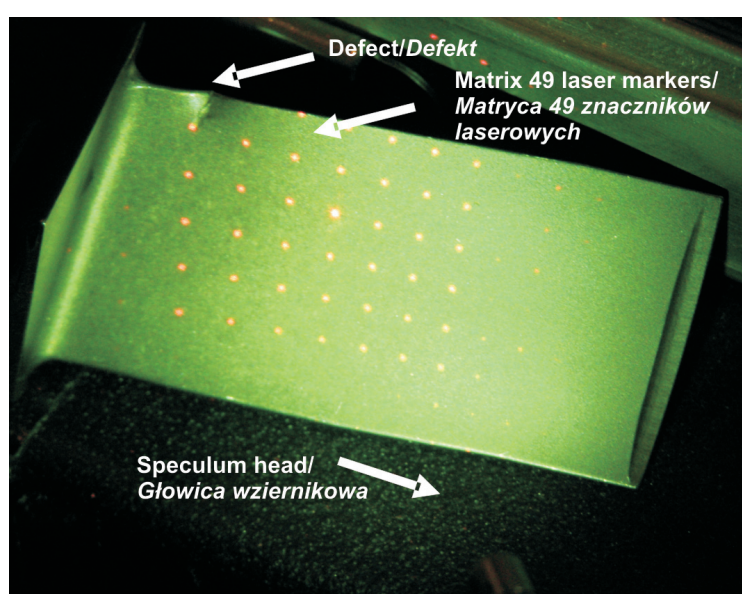

b)

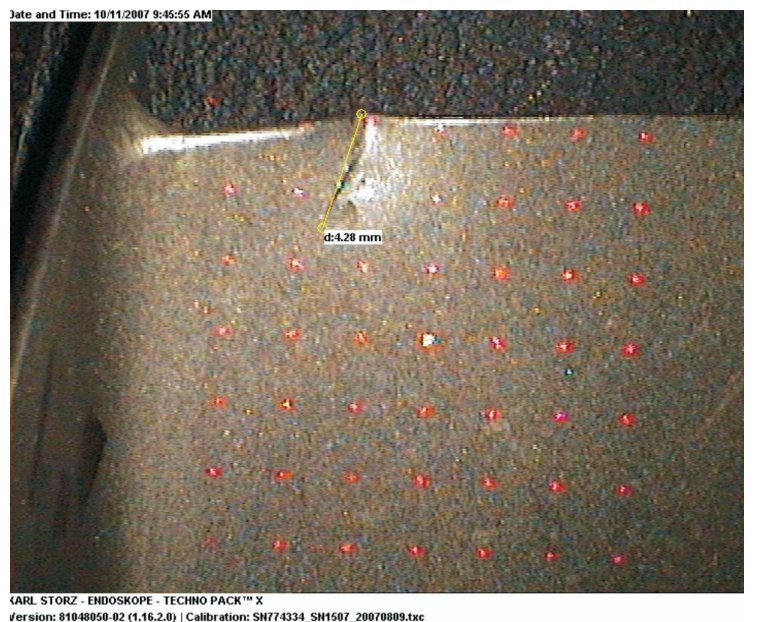

Fig. 16. Measurement of a turbine vane defect with the use of the marker method by STORZ: a) a view of the turbine vane after projecting the laser matrix, b) measurement of the length of the indentation on the edge of the vane Rys. 16. Pomiar defektu łopatki turbinowej z wykorzystaniem znacznikowej metody laserowej STORZ: a) widok topatki turbinowej po nałożeniu laserowej matrycy wideoskopu, b) pomiar dhugości wgniecenia na krawędzi splywu topatki turbinowej zwierciadeł. Rozproszona wiązka laserowa padająca na badaną powierzchnię ulega odbiciu, które ukierunkowane jest na soczewkę skupiającą i detektor pomiarowy. Ilość odbitego światła laserowego zależna jest od stanu badanej powierzchni. Jeżeli skanujący promień laserowy przesunie się nad defektem powierzchniowym, nastąpi absorpcja wynikająca z mniejszej ilości odbitego światła. W konsekwencji natężenie odbitego światła (gęstość strumienia świetlnego na soczewce skupiającej) jest mniejsze niż w przypadku powierzchni wolnej od defektu. Ocena wymiarowa wykrytych defektów powierzchniowych dokonywana jest na podstawie analizy spektralnej rozproszonej wiązki laserowej w komputerowym programie analizującym skanera - rys. 17b. Zastosowanie optyki cylindrycznej w układzie skanera laserowego bardzo zwiększa jego walory aplikacyjne (promień laserowy rozpraszany jest w ciagłą linię obwodowa), dając możliwość oceny stanu technicznego mniejszych powierzchni, np. przestrzeni wewnętrznych silników spalinowych, w szczególności przestrzeni wewnątrzcylindrowych silników tłokowych.

\subsection{Metoda RGB}

Obraz cyfrowy zapisany w komputerze wideoskopu składa się z oddzielnych elementów, tzw. pikseli, z których każdy specyfikowany jest jako grupa wartości barw czerwonego, zielonego i niebieskiego komponentu obrazu w tym punkcie, tzw. format RGB. Z ich odpowiedniego zmieszania można uzyskać wszystkie inne barwy. Każdą z barw formatu RGB charakteryzuje odcień, stopień jasności (lub jaskrawości), stopień nasycenia i czystość. Należy podkreślić, że barwa jako szczególna właściwość przedmiotów materialnych wyróżniana wzrokowo zależna jest od ich struktury fizycznochemicznej, od sposobu absorbowania i odbijania promieni świetlnych przez obserwowaną powierzchnię, od charakteru samego światła, od właściwości powietrza i od specyfiki otoczenia (refleksy świetlne). Biorą pod uwagę charakterystyczne cechy barw, można dokonać prostej analizy spektralnej kompozytu kolorowego zarejestrowanego obrazu powierzchni elementu konstrukcyjnego i na tej podstawie ocenić jej strukturę. Ponieważ pewne defekty powierzchniowe, jako zmiany właściwości fizycznych materiału konstrukcyjnego, charakteryzują się ściśle określonym wzorcem widma barw, można za pośrednictwem analizy porównawczej obrazów widmowych rozpoznać niekorzystne zmiany struktury we wczesnym stadium ich rozwoju. Dodatkowe informacje diagnostyczne mogą wnosić analizy cech zapisu cyfrowego na granicach poszczególnych barw: ich ostrość, jaskrawość, gęstość powierzchniowa itd.

Interesujące badania nad diagnostycznym wykorzystaniem informacji zawartych w cyfrowych obrazach części silników lotniczych (w szczególności łopatek turbinowych) prowadzi zespół prof. Józefa Błachnio z Politechniki Białostockiej. W opracowaniu [1] zaproponowano metodę oceny zmian mikrostruktury warstwy wierzchniej łopatek wirnikowych turbin silników lotniczych na podstawie analizy sygnału świetlnego odbitego od ich powierzchni. Dokonywany rozkład widmowy RGB zarejestrowanego obrazu łopatki daje jakościową i ilościową ocenę stopnia przegrzania jej struktury. Możliwe jest również określenie 
a)

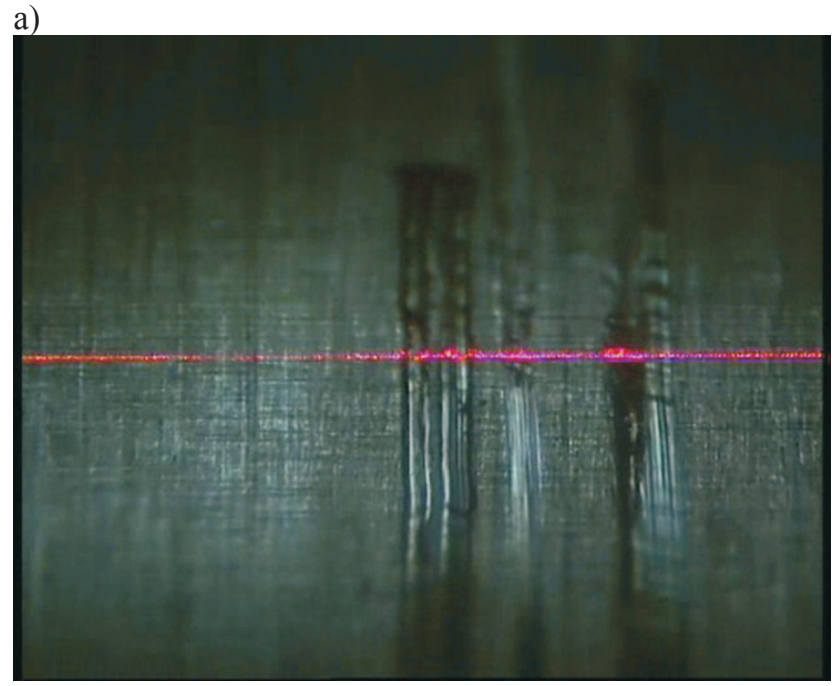

b)

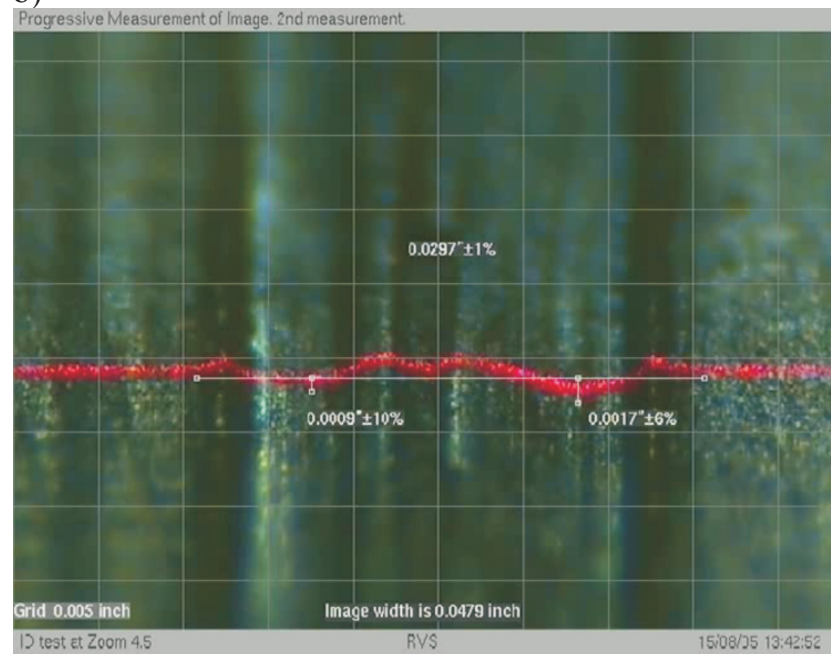

Fig. 17. Measurement of surface defects (traces of friction) with the use of scanning laser method SMDS [7]: a) laser beam scanning the surface, b) measurement of the surface deformations (surface indentations and bulges) by a laser method

Rys. 17. Pomiar defektów powierzchniowych (ślady tarcia) z wykorzystaniem skanerowej metody laserowej SMDS [7]: a) promień laserowy skanujacy badanq powierzchnię, b) pomiar deformacji powierzchniowych (wgłębienia i wypukłości powierzchni) metoda laserowa

Interesting research related to diagnostic use of information stored in digital images of parts of aviation engines (turbine vanes in particular) has been conducted by a team of professor Józef Błachnio from Bialystok University of Technology. In paper [1] a method of assessment of microstructural surface changes of turbine vanes in aviation engines has been proposed based on the analysis of the light signal reflected from the surface. The performed RGB spectral analysis of the recorded image of a vane provides a qualitative and quantitative assessment of the level of structure overheating. Determining of other surface defects including surface attrition is also possible. The key condition for the repeatability of the RGB measurement and consequently the credibility of the diagnostic reasoning is providing identical conditions of the photography - a specially designed test stand (reflexes eliminated). This obviously necessitates a retrieval of the vanes from the turbine which is not always possible in operating conditions.

Within the diagnostic tests of marine engines run by the author's team an attempt to apply the RGB method has been made to assess the level of carbon deposit in the combustion chamber. The recorded results of routine endoscopic examinations of machines operation were used - Fig. 18. The images were stored in the JPEG format. Even though the tests were only preliminary a stress was put on the behavior of a comparable light intensity on the piston crown at the same crankshaft angle. Due to the specific character of the assessment (intensity of the surface attrition only) the authors gave up full analysis of the intensity of color distribution and fully analyzed the intensity of the distribution of the shade of gray of monochromatic images. The presented method is based on Able Image Analyzer v3.6, which analyzes images in terms of its pixel intensity of individual colors or pixel intensity of shades of gray. innych defektów powierzchniowych materiału konstrukcyjnego, a także intensywności zanieczyszczenia powierzchni łopatki. Kluczowym warunkiem powtarzalności pomiaru metodą RGB, a w konsekwencji wiarygodności wnioskowania diagnostycznego jest zapewnienie identycznych warunków fotografowania łopatek, na specjalnie w tym celu skonstruowanym stanowisku badawczym (wyeliminowanie efektów refleksyjnych). Wiąże się to oczywiście z konieczności demontażu łopatek z silnika, a to nie zawsze jest możliwe w warunkach eksploatacji.

W ramach badań diagnostycznych silników okrętowych prowadzonych przez zespół badawczy autora niniejszego opracowania podjęto również próbę zastosowania metody RGB do oceny stopnia zanieczyszczenia nagarem powierzchni ograniczającej komorę spalania układu cylindrowego. Wykorzystano w tym celu zarejestrowane wyniki rutynowych badań endoskopowych silnika w bieżącej eksploatacji - rys. 18. Zdjęcia zapisano w formacie JPEG. Pomimo iż podejmowane badania miały ty charakter tylko pilotażowy, to jednak podczas akwizycji obrazów zwracano szczególną uwagę na zachowanie porównywalnego natężenia oświetlenia obserwowanych powierzchni denka tłoka, dokonując zapisu w tym samym jego położeniu względem GMP. Ze względu na charakter dokonywanej oceny (tylko intensywność zanieczyszczenia powierzchni) zrezygnowano z pełnej analizy intensywności rozkładu barw na rzecz intensywności rozkładu odcieni szarości obrazów monochromatycznych. Przedstawiona metoda bazuje na programie użytkowym Able Image Analyser v3.6, który analizuje obraz pod względem intensywności występowania pikseli danego koloru lub pikseli odcieni szarości.

$\mathrm{Z}$ danych liczbowych zamieszczonych na histogramach oraz w tabeli 1, sporządzonych dla 3 różnych przypadków zanieczyszczenia powierzchni denka tłoka rozpatrywanego silnika okrętowego wynika, że możliwa jest nie tylko jako- 
From the numerical data in the histograms and Table 1, made from 3 different cases of piston crown attrition in the marine engine under analysis we can infer that not only the qualitative but also quantitative assessment of the attrition level of the combustion chamber is possible (piston crown in this case). Yet, a serious problem limiting the utilitarian features of this method is the repeatability of the conditions of image acquisition which cannot be ensured on a ship during its operation. ściowa, ale również ilościowa ocena intensywności zanieczyszczenia sadzą powierzchni zespołu komory spalania (w tym przypadku denka tłoka). Jednak istotnym problemem znacznie ograniczającym walory utylitarne proponowanej metody jest powtarzalność warunków akwizycji obrazu, która w warunkach eksploatacji silników na okręcie nie może być zapewniona.
Digital image of a surface of a piston crown - marine engine/ Obraz cyfrowy powierzchni denka tłoka silnika okrętowego
Level of monochromatic image saturation with shades of gray/ Poziom nasycenia obrazu monochromatycznego odcieniami szarości
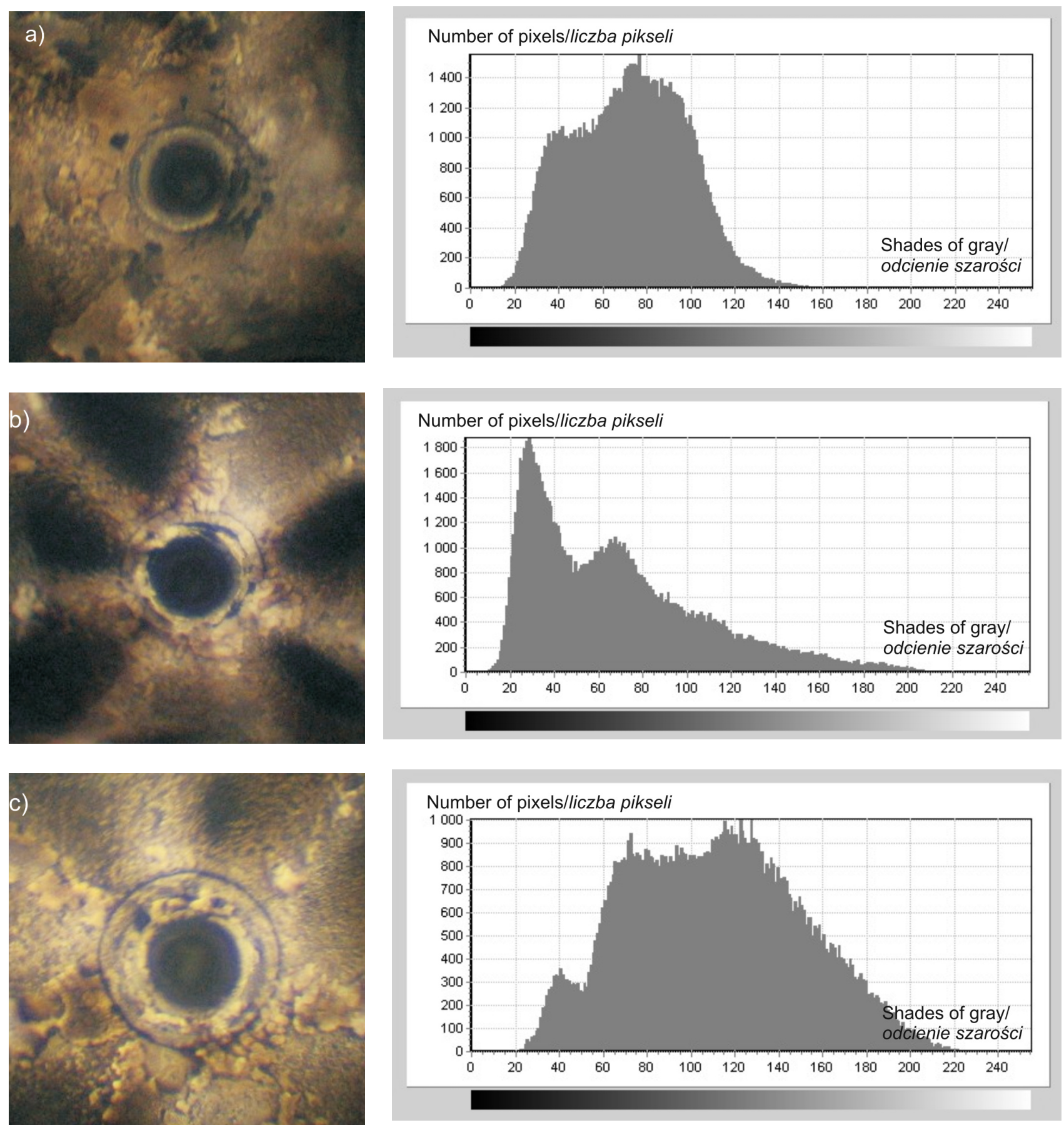

Fig. 18. Results of measurements of the intensity of carbon deposit on a piston crown - RGB method Rys. 18. Wyniki pomiaru intensywności zanieczyszczenia nagarem powierzchni denka tłoka metoda $R G B$ 


\section{Conclusions}

Detection of material defects through endoscopy is one of the youngest methods in technical as opposed to medical diagnostics, which since ancient times has been the key method for identification of pathology inside the human body.

The here presented optical (qualitative) and digital (quantitative) methods of endoscopy are more and more frequently used in the assessment of technical condition of complex machinery. These methods are an efficient diagnostic tool which is also popular among marine engine technicians (marine piston and turbine engines) of both the navy and commercial shipowners.

The implementation of endoscopy in routine diagnostic inspections of marine engines in the Polish Navy enables the evaluation and prognostics of deterioration and early failure detection inside the machinery susceptible to damage. This allows a rational planning of the process of machinery operation while the costs are considerably lowered up to $25 \div 30 \%$.

As a result of the systematic endoscopic inspections a plethora of material defects have been identified which if neglected could have led to a serious engine damage. In many cases the engines did not show any clearly visible symptoms of failure (operation of an engine with a cracked cylinder sleeve or damaged vanes of a turbo compressor) $[10,15]$.

\section{Bibliography/Literatura}

[1] Błachnio J., Bogdan M.: A non-destructive method to assess a degree of overheating of gas turbine vanes. Journal of Polish CIMAC. Diagnosis, Reliability and Safety. Vol. 2, No. 2, 2007.

[2] Breen J., Stellingwerff M.: Application of optical and digital endoscopy. Proceedings $2^{\text {nd }}$ EAEA-Conference. Vienna 1995.

[3] Brześcińska W.: Fotogrametria. Wydawnictwo Szkolne i Pedagogiczne. Kraków 1998.

[4] Doglietto F., Prevedello D.M., Jane J.A., Han J., Laws E.R.: A brief history of endoscopic transsphenoidal surgery - from Philipp Bozzini of the first World Congress of Endoscopic Skull Base Surgery. Neurosurgery Focus. Vol. 19, 2005.

[5] Gardner A.P.: How to excel in endoscopic photography. British Journal of Urology. No. 81, 1998.

[6] Hlebowicz J.: Endoskopia przemysłowa. Biuro Gamma. Warszawa 2000.

[7] Industrial endoscopy system guide. Version 2. Oferta OLYMPUS Industrial.

[8] InspectCam SDMS laser measurement system. Fast and Accurate. Oferta REMOTE VISION SOLUTIONS Pty Ltd.

[9] Korczewski Z.: Endoscopic examination of naval gas turbines. Polish Maritime Research, No. 4, 1998.

[10] Korczewski Z.: Identyfikacja uszkodzeń układów turbodoładowania w eksploatacji silników okrętowych. Zeszyty Naukowe AMW nr 4(171)/2007 r., s. 57-78.

[11] Rainer M.E.: Philipp Bozzini - the father of endoscopy. Journal of Endourology. No. 17, 2003.

[12] Remote visual inspection. Product guide. Oferta OLYMPUS Industrial.

[13] Techno pack with multipoint measuring system. Oferta KARL STORZ - Endoscope. Industrial Group.

[14] XL PRO videoprobe measurement system. Oferta EVEREST VIT.

[15] Sprawozdania z badań diagnostycznych tłokowych i turbinowych silników spalinowych eksploatowanych na okrętach MWRP - Prace badawcze AMW, Gdynia 1992-2008.
Table 1. Absolute and percentage values of the level of saturation with shades of gray of a monochromatic image of the surface of the piston crown for cases in Fig. 18a, b and c

Tabela 1. Wartości bezwzględne i procentowe poziomu nasycenia odcieniami szarości obrazu monochromatycznego powierzchni denka tłoka dla przypadków z rys. $18 a, b$ ic

\begin{tabular}{|l|c|c|c|c|c|c|}
\hline Fig. 18 & \multicolumn{2}{|c|}{ a } & \multicolumn{2}{c|}{ b } & \multicolumn{2}{c|}{$c$} \\
\hline Interval & Count & Percent & Count & Percent & Count & Percent \\
\hline $0-49$ & 24069 & 23.36 & 42771 & 41.51 & 5822 & 5.65 \\
\hline $5-99$ & 64290 & 62.39 & 39844 & 38.67 & 37114 & 36.02 \\
\hline $100-149$ & 14593 & 14.16 & 15571 & 15.11 & 42301 & 41.05 \\
\hline $150-199$ & 89 & 0.09 & 4662 & 4.52 & 16919 & 16.42 \\
\hline $200-249$ & 0 & 0.00 & 193 & 0.19 & 885 & 0.86 \\
\hline $250-55$ & 0 & 0.00 & 0 & 0.00 & 0 & 0.00 \\
\hline
\end{tabular}

\section{Podsumowanie}

Wykrywanie wad materiałowych maszyn i urządzeń przemysłowych z wykorzystaniem endoskopów jest jedną z najmłodszych metod diagnostyki technicznej, w przeciwieństwie do diagnostyki medycznej, która od czasów starożytnych jest uznawana za kluczową metodę poszukiwania stanów patologicznych wewnątrz ludzkiego ciała.

Przedstawione w artykule optyczne (jakościowe) i cyfrowe (ilościowe) metody wziernikowania przestrzeni wewnętrznych z wykorzystaniem endoskopów i wideoskopów przemysłowych są coraz chętniej stosowane w ocenie stanu technicznego złożonych obiektów technicznych. Stanowia bardzo efektywne narzędzie diagnostyczne, po które również coraz częściej sięgają eksploatatorzy silników okrętowych (tłokowych i turbinowych) zarówno flot wojennych, jak i wielu armatorów cywilnych jednostek pływających.

Wdrożenie metod endoskopowych do rutynowych badań diagnostycznych silników okrętowych eksploatowanych w Marynarce Wojennej RP daje możliwość oceny i prognozowania intensywności zużycia oraz wczesnego wykrycia uszkodzeń w ich przestrzeniach roboczych zagrażających awaria. Pozwala to racjonalnie planować proces eksploatacji silników według aktualnego stanu technicznego, przy znacznym obniżeniu kosztów eksploatacji, jak się szacuje - nawet do $25 \div 30 \%$.

W wyniku prowadzonych systematycznie przeglądów endoskopowych zidentyfikowano wiele defektów materiałowych, które w przypadku dalszego rozwoju stanowić mogły istotne zagrożenie dla niezawodności silnika. $\mathrm{W}$ wielu przypadkach silniki nie generowały obserwowalnych symptomów zaistniałych uszkodzeń, czego przykładem może być kontynuacja pracy z pękniętą tuleją cylindrową czy z mechanicznymi uszkodzeniami ułopatkowania wirnika turbosprężarki $[10,15]$.

\section{Artykut recenzowany.}

Mr Zbigniew Korczewski, DSc, DEng - Commodore and Professor in the Polish Naval Academy in Gdynia.

Kmdr dr hab. inż. Zbigniew Korczewski - Dziekan Wydzialu Mechaniczno-Elektrycznego, Akademia Marynarki Wojennej w Gdyni. 